\title{
Mortality Risk Factors in Micro and Small Businesses: Systematic Literature Review and Research Agenda
}

\author{
Fabiane Tubino Garcia ${ }^{1,2, *(D)}$, Carla Schwengber ten Caten ${ }^{1}$, Elaine Aparecida Regiani de Campos ${ }^{1}$, \\ Aline Marian Callegaro ${ }^{3}$ and Diego Augusto de Jesus Pacheco ${ }^{4}$
}

1 Engineering Department, Universidade Federal do Rio Grande do Sul, Porto Alegre 90035-190, Brazil; carla.caten@ufrgs.br (C.S.t.C.); elaine.campos@ufrgs.br (E.A.R.d.C.)

2 Business and Economics Department, Universidade Federal do Pampa, Sant'Ana do Livramento 97573-634, Brazil

3 Interdisciplinary Department, Universidade Federal do Rio Grande do Sul, Tramandaí 95590-000, Brazil; aline.callegaro@ufrgs.br

4 Department of Business Development and Technology, Aarhus University, 7400 Herning, Denmark; diego@btech.au.dk

* Correspondence: fabianegarcia@unipampa.edu.br

check for

updates

Citation: Garcia, F.T.; ten Caten, C.S.; de Campos, E.A.R.; Callegaro, A.M.; de Jesus Pacheco, D.A. Mortality Risk Factors in Micro and Small Businesses: Systematic Literature Review and Research Agenda. Sustainability 2022, 14, 2725. https:// doi.org/10.3390/su14052725

Academic Editor: Sooksan Kantabutra

Received: 26 December 2021 Accepted: 16 February 2022 Published: 25 February 2022

Publisher's Note: MDPI stays neutral with regard to jurisdictional claims in published maps and institutional affiliations.

Copyright: (C) 2022 by the authors. Licensee MDPI, Basel, Switzerland. This article is an open access article distributed under the terms and conditions of the Creative Commons Attribution (CC BY) license (https:// creativecommons.org/licenses/by/ $4.0 /)$.

\begin{abstract}
Most micro and small businesses (MSEs) are limited in organizational structure, financial resources, technology, and management strategies. Due to these limitations, there are many risks involved in this sector. Understanding the aspects that contribute to the risk of mortality among MSEs is important to guide entrepreneurs in the development of strategic actions and to assist governments in the elaboration of policies that support the creation of new ventures. For this, it is important to know the key factors that contribute to the risk of business mortality. Thus, the following research questions emerge: What is the state of the art on the subject of business mortality in MSE? What are the factors that contribute to the risk of mortality in MSE? What is the relationship between the factors that contribute to the risk of mortality in MSE? The objective of this research was to analyze what the risk factors are for MSE mortality and how they are related to each other. From a systematic literature review, the state of the art on the topic of business mortality in MSEs was evidenced and its risk factors were identified. One hundred and six articles, published from January 2000 to February 2021, were analyzed. The results showed 36 mortality risk factors and highlighted the risks associated with innovative processes, business management, and the characteristics of the entrepreneur. This study contributes to a theoretical framework on corporate mortality and provides an agenda for future research, showing gaps to be explored. In terms of managerial implications, we suggest that entrepreneurs prioritize training initiatives, investing in education, that MSEs participate in cooperation networks to establish partnerships between stakeholders, and that they invest in technological tools to make companies more competitive in the market.
\end{abstract}

Keywords: business mortality; risk factors; MSE; systematic review; conceptual framework; research agenda

\section{Introduction}

Entrepreneurship is considered one of the main drivers of economic growth, and therefore plays an important role in national economies [1,2]. From this perspective, micro and small enterprises (MSEs) play significant roles in the growth of the Gross Domestic Product (GDP), the generation of jobs, income distribution, and socioeconomic development [3,4]. Furthermore, they favor stability and social equity for the low-income population through entrepreneurship and business formalization [5].

MSEs represent the majority of the total number of companies in most countries [6,7] and, because of their diversity, they are generally classified regarding the number of employees, annual turnover, and amount of total annual assets [8]. MSEs are fragile and 
are exposed to risks in the initial years of operation, a period in which entrepreneurs are learning to operate a new business [9]. Therefore, it was verified that the time variable impacts the risk of business mortality, since newer ventures demonstrate greater chances of failure in the first years of activity in the market [10]. Another important point that influences the risk of mortality is the size of the company; that is, the larger the enterprise, the greater the chances of its continuity [11]. Furthermore, many of these companies are unregulated and lack strategic and technological training to avoid business mortality $[12,13]$. Studies show that most MSEs are limited in development, working capital, organizational structure, and management strategy [14].

Business mortality is understood as the extinction of production factors, with the condition that no other organization is involved in the process, such as in cases of mergers and company restructuring [10]. There is a consensus in the literature that there is no isolated factor that determines the risk of business mortality, but rather a dynamic relationship of internal and external difficulties $[15,16]$.

Factors associated with the risk of mortality can be broadly divided into (a) entrepreneur, which refers to the characteristics of the individual and the lack of previous experience; (b) company or business, which presents the problems in the management of the company, and (c) external environment, where there are difficulties related to the economic context and other factors of a cyclical nature [11,16]. Mahamid [17] presents another classification: (a) managerial factors, (b) financial factors, and (c) external factors. The systemic understanding of risk factors is relevant to helping other entrepreneurs overcome similar problems, carrying out planning that reduces the risk of mortality [16]. Literature suggests that business mortality risk factors are related to non-incorporation in business networks [18,19], the difficulty of accessing financing and loans [20,21], and the lack of technological tools [22,23]. Lack of management experience [24] and technical knowledge $[25,26]$ also result in significant business mortality rates.

The present review's emphasis on understanding the dynamic relationships that influence MSE mortality was based on the gaps observed in the literature. Despite the growth of studies in the area, there is a lack of generality in the findings, and several research problems remain nuclear. Ferreira et al. [16] ensure that the level of integration between aspects related to risk is practically inseparable. Gupta and Tripathi [24] add that this topic has potential for future studies, as many factors should be analyzed to improve the performance of MSEs and help the local economy.

Another important aspect is that entrepreneurship is a global trend, and in this scenario, MSEs represent the majority of companies worldwide [25]. Understanding the problems and challenges of MSEs has gained importance at the social, governmental, business, and academic levels [24,26]. Furthermore, a nation's macroeconomic policies and government attitudes in this regard influence both the failure and success of any endeavor [27]. Roratto et al. [28] add the need to develop instruments that can reduce business mortality and create programs that incorporate accumulated theoretical and empirical knowledge.

Considering the above gaps, the following research questions emerged:

RQ1. What is the state of the art on the subject of business mortality in MSEs?

RQ1a. What are the factors that contribute to the risk of mortality in MSEs?

RQ2. What is the relationship between the factors that contribute to the risk of mortality in MSEs?

The main objective of this research was to analyze the factors that contribute to the risk of mortality in MSEs. The specific objectives were: (i) to investigate the state of the art on the subject of business mortality in MSE, and (ii) to verify the existing relationships between the factors that contribute to the risk of mortality in MSE. For the development of this study, the method by Confort et al. [29] was carried out in ten steps. A conceptual model was developed to identify the relationships between the factors and a future research agenda. This research brought theoretical and managerial contributions. First, it offered a theoretical framework for business mortality. The analysis revealed the growth of studies 
on the subject in recent years, highlighting the method of empirical statistics in most of the articles analyzed. It contributed to the identification of future research and gaps to be explored in segments of interest, with methodologies that bring answers to the sector. Second, it contributed to understanding of the determinants of mortality risk in MSEs and their relationships. A comprehensive analysis of the literature revealed thirty-six risk factors, which were classified into five key dimensions. These findings contributed to entrepreneurs prioritizing improvement and training initiatives. The results showed a set of critical factors that lead to the risk of mortality, highlighting the risks associated with innovative processes, business management, and the characteristics of the entrepreneur. Third, this article helps policymakers and other stakeholders working in MSE to find knowledge to support the creation of new ventures and business growth.

In terms of managerial implications, it is suggested that entrepreneurs invest in education, so that their decisions are based on technical knowledge and not on intuition; that MSEs participate in cooperation networks to establish formal and informal partnerships between stakeholders; that they invest in technological tools to make MSEs more competitive in the market, and that an investigation is carried out to collect information on customers' consumption needs and desires, limitations and habits, taking into account their complaints and comments on social media. This study was organized into eight sections. Section 2 describes the methodological procedures and steps followed in this systematic review. Section 3 details the results of the state-of-the-art literature in the field. Section 4 presents the discussion and implications of the research results. In Section 5, the dimensions and subdimensions that justify the proposed model are presented, and Section 6 brings a conceptual model that structures the relationship between mortality risk factors in MSEs. Section 7 details an agenda for future research, and finally, Section 8 summarizes the findings and the managerial implications.

\section{Materials and Methods}

This section presents all the steps taken for the systematic literature review. A systematic literature review is a secondary study used to map, critically assess, consolidate, and aggregate the results of relevant primary studies about a specific research question or topic [30]. As Tranfield et al. [31] affirm, the objective of the systematic review is to provide insights, yielding reliable and accumulated knowledge of a range of studies. Furthermore, it identifies gaps to be filled, resulting in a coherent report or synthesis. This study used the review method devised by Confort et al. [29] structured in 10 steps. In the presentation of the results, a synthesis was carried out, based on the thematic categories of corporate mortality risks proposed by Ferreira et al. [16] and Machado and Espinha [11].

Step 1. Definition of the research problem: what are the factors that contribute to mortality risk in MSEs?

Step 2. Definition of the objective: to analyze the factors that contribute to mortality risk in MSEs.

Step 3. Primary sources. The databases used were: Web of Science, Scopus, Science Direct, and Taylor and Francis. The Web of Science was chosen because it is considered the largest scientific database in the world and includes the most cited journals in their respective areas, Scopus and Taylor and Francis were selected for their academic-level and multidisciplinary information sources, and Science Direct was chosen in order to incorporate the areas of applied Engineering and Social Sciences. Initially, the terms 'business mortality' and 'micro and small business' were researched to verify citations in other publications. The words related to business mortality were: bankruptcy, business closure, business closure, early mortality, failure, business discontinuity, and failure. For 'micro and small business', the associated words were: microenterprise, small enterprise, small businesses, small and medium enterprises, MSEs, and SMEs (small and medium enterprises). All terms were added to the search. 
Step 4. Keywords. The combinations presented in step 3 were considered in the analysis of the abstract and title of the paper. The keywords searched were: micro and small enterprise, MSE, SME, premature mortality of enterprise, the closing of business, and company bankruptcy. Example of a combination of keywords searched in the databases: ('micro and small enterprise*' OR 'MSEs' OR 'SMEs') AND ('premature* mortality* of enterprise $^{* \prime}$ ) AND ('closing* of business"') AND ('company* bankruptcy*').

Step 5. Definition of the survey period. The covered period ranged from January 2000 to February 2021. This review started with the year 2000, because it was found that studies on corporate mortality had more publications from this period onwards, that is, an average of 60 articles were published per year. Furthermore, from the 1960s to the 1990s, only a limited number of studies were published, with a mean of 6 papers published per year.

Step 6. Criteria for inclusion and exclusion of articles. After reading the title and abstract verified in step 4, the filters used for selection were: (a) studies on critical mortality risk factors in MSE; (b) type of document, for which only scientific papers were selected, and (c) the language of publication, considering articles in English. Duplicate articles and those that did not respond to the problem of this study were excluded.

Step 7. Article qualification criteria. The introduction and conclusion of the papers selected in step 6 were read to verify the focus of the research. The number of citations of the article and descriptive and explanatory studies were considered.

Step 8. Methods and tools. The method included the steps that facilitated learning and filtering the search process. A complete reading of the selected articles was carried out for a better understanding.

Complementing the previous steps, the Systematic Reviews and Meta-Analyses Protocol (PRISMA) was used (Figure 1), which aims to improve the reporting and evaluation of systematic reviews in a given area, making it complete and transparent [32]. This protocol was structured in four stages: identification, selection, eligibility and, inclusion. During identification, relevant studies were sought, resulting in a total of 1971 articles. In selection, a double screening was performed. Duplicate articles were excluded $(n=107)$ and the analysis of titles and abstracts was performed, with articles that did not present a relationship between the search terms being eliminated $(n=949)$. On eligibility, the studies were read and analyzed. Articles that did not answer the research questions and those that did not mention mortality risk factors or determinants were excluded, as well as studies that dealt with another type of company $(n=838)$. It was found that although the term 'micro and small business' was among the keywords, some articles that did not include this sector appeared as a results.

In the last stage, 77 articles were included. In the end, the Snowball method was applied, capturing 29 articles. This technique was used to select additional works from early paper references [33]. Thus, 29 works were added to 77 articles, totaling 106.

Steps 9 and 10. Processing and output. A spreadsheet with the 106 selected papers was created (Appendix A). In the final step, based on the findings in the literature, a conceptual model [34-36] that organized the existing relationships between the risk determinants found was created.

As for the philosophy of scientific research, it was verified that it is a method that, when applied in different areas, allows the researcher to generate ideas in knowledge in the context of research. There are four main trends in research philosophy that are distinguished and discussed, namely: positivist research philosophy, interpretivist research philosophy, pragmatist research philosophy, and realist research philosophy [37].

This study is guided by the interpretivist research philosophy. The interpretivist research philosophy says that the social world can be interpreted subjectively. The greatest attention here is given to understanding the ways in which people experience the social world. The interpretivist research philosophy is based on the principle that the researcher plays a specific role in observing the social world. According to this philosophy, research is based on and depends on what the interests of the researcher are. It is noteworthy that interpretive research uses qualitative methods, mostly, and the following data collection 
techniques: document study, image data analysis, observation and interview. This research works with interpretation, with the creation of theories, where researcher and reality are mixed. In this study, the interpretivist approach fits the need to study a phenomenon (business mortality risk) to seek an answer, where knowledge is not constructed and the objective of the research is a broad description of the phenomenon under study [37].

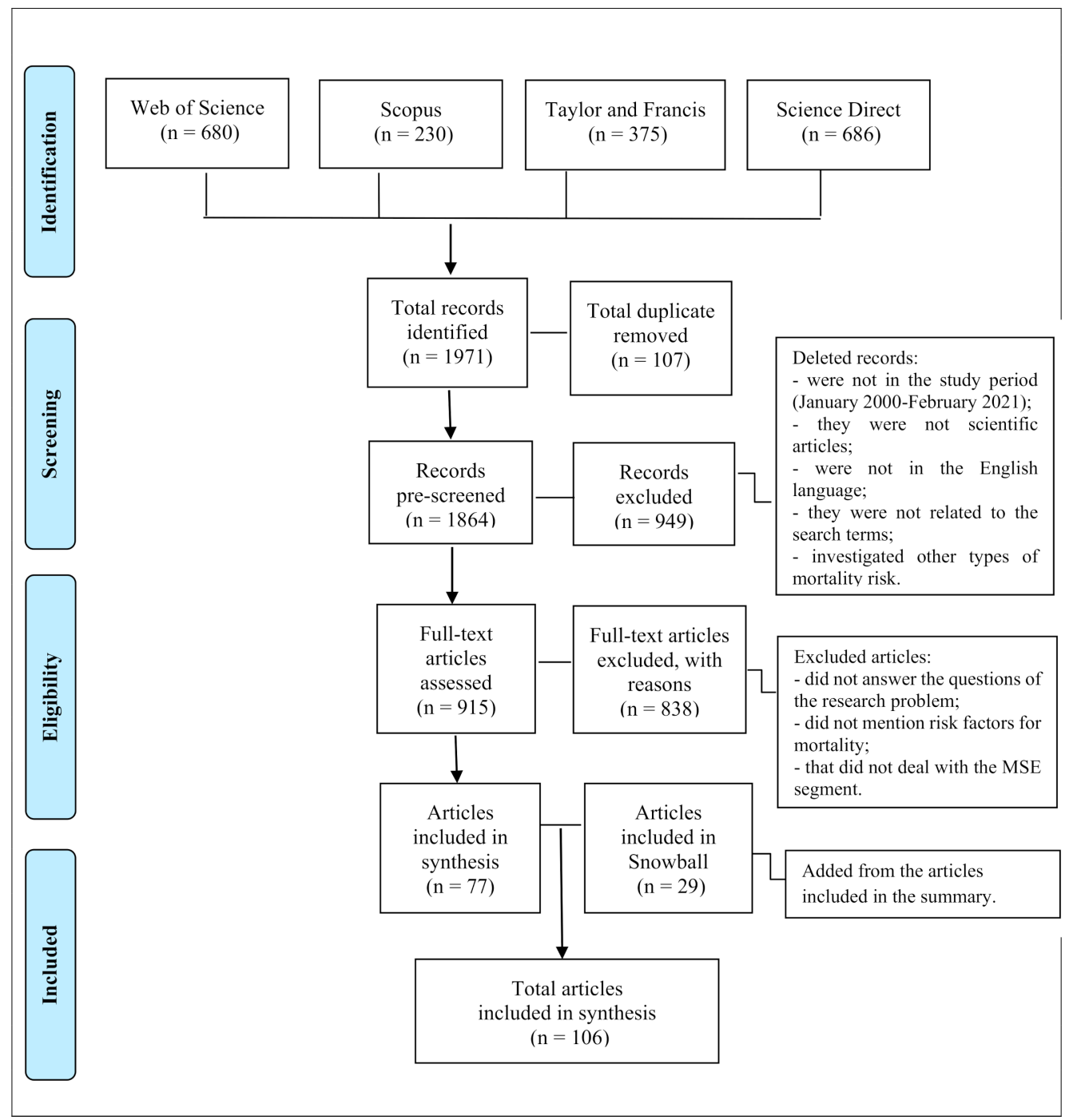

Figure 1. Steps of the PRISMA protocol for systematic literature review.

\section{Results}

This section presents the results identified in the 106 analyzed studies.

\subsection{Descriptive Analysis}

The final selection of articles was presented in terms of stratification, publications by year, and countries.

With the use of keywords, the database with the highest number of relevant studies was Science Direct $(n=686)$ (Figure 2). After the first and second screening process, Web of Science stood out for the largest number of selected articles (37). In Filter 1, duplicated articles in the databases were excluded, and in Filter 2, the papers were read and analyzed (Figure 2). 


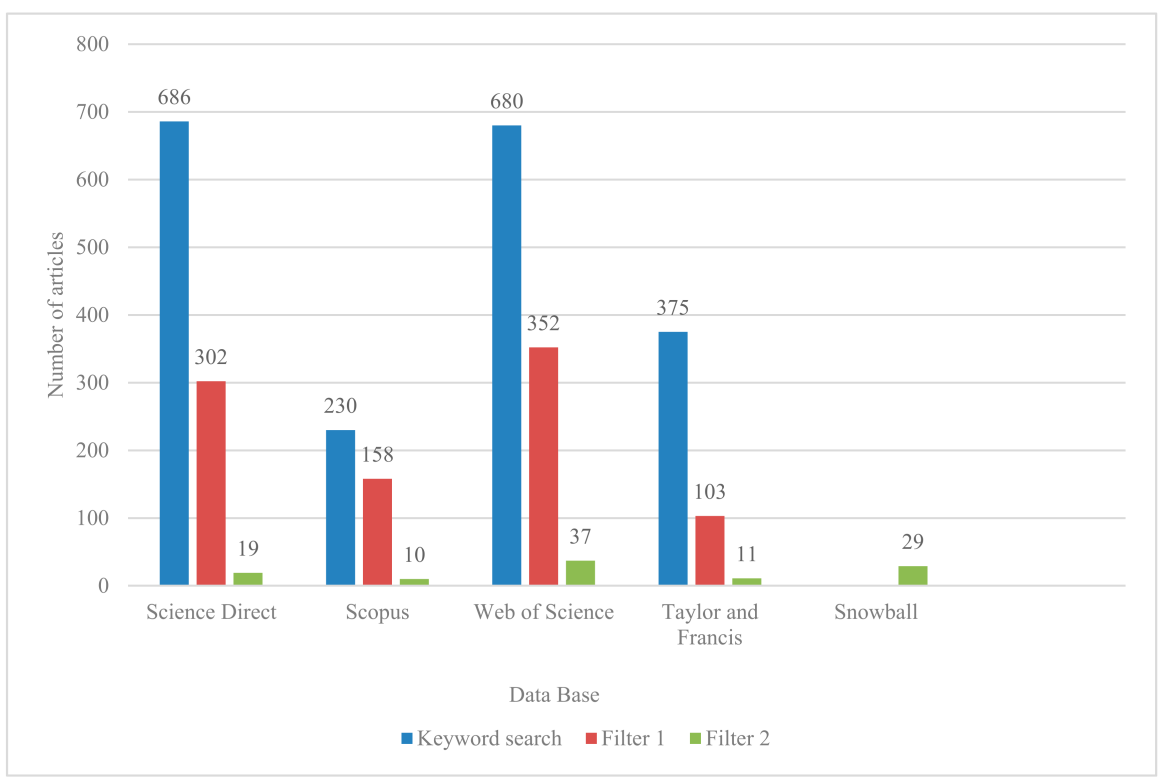

Figure 2. Number of publications by databases and Snowball.

In the last ten years (2010-2020), the number of articles published increased. Out of the 106 papers analyzed, 92 were published in this period (Figure 3). The years with the highest number of articles analyzed were 2019 and 2020, with 16 and 18, respectively.

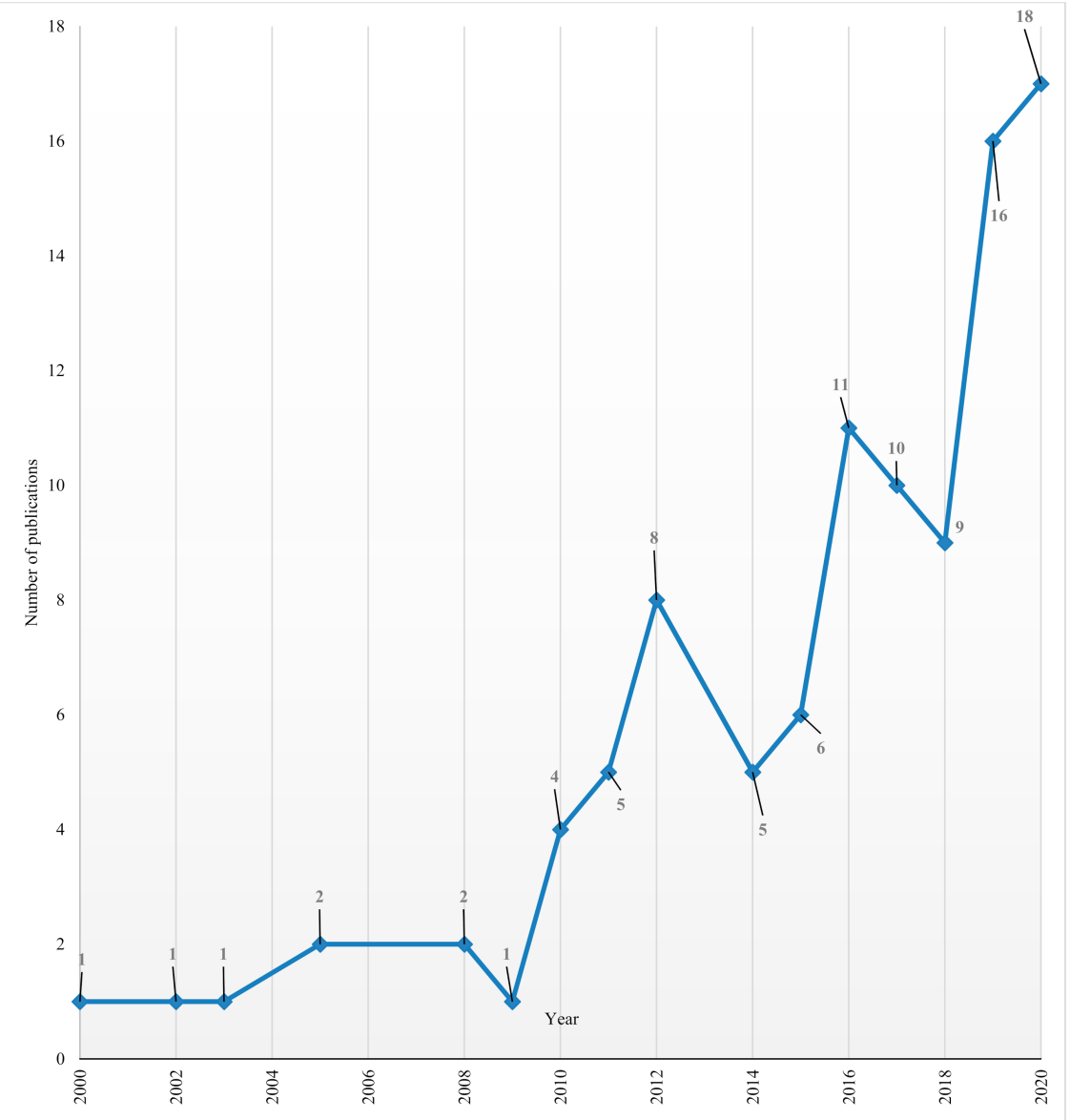

Figure 3. Number of publications per year selected. 
The articles were published in 19 different countries. The countries that had the highest numbers of publications were the United Kingdom, Brazil, and the Netherlands, with 39, 18 , and 12, respectively. Next was the United States, with eight papers, and India, with seven. Despite its relevance, the topic has not been studied in most countries.

The selection of articles was presented in terms of general characteristics [38], the most productive journals and authors, and the most relevant keywords.

Considering Table 1, the total number of publications (TP) increased from one in 2000 to nineteen in 2020. In 2021, the six publications were from January and February, when data collection ended. There was also an increase in the total number of authors (AU), from three in 2000 to fifty-five in 2020. The page count in each journal (PG) grew in the period 2016-2020, which justifies the concern with the research problem.

Table 1. General and annual characteristics of selected articles.

\begin{tabular}{cccccc}
\hline Year & TP & AU & PG & AU/TP & PG/TP \\
\hline 2000 & 1 & 3 & 9 & 3.0 & 9.0 \\
2002 & 1 & 3 & 18 & 3.0 & 18.0 \\
2003 & 1 & 1 & 11 & 1.0 & 11.0 \\
2005 & 2 & 3 & 27 & 1.5 & 13.5 \\
2008 & 2 & 3 & 18 & 1.5 & 9.0 \\
2009 & 1 & 1 & 12 & 2.3 & 12.0 \\
2010 & 4 & 9 & 64 & 2.8 & 16.0 \\
2011 & 5 & 14 & 72 & 2.6 & 14.4 \\
2012 & 8 & 21 & 84 & 3.3 & 10.5 \\
2014 & 5 & 10 & 83 & 2.5 & 8.6 \\
2015 & 6 & 20 & 144 & 2.5 & 14.2 \\
2016 & 11 & 27 & 147 & 3.2 & 13.1 \\
2017 & 10 & 25 & 169 & 2.5 & 14.7 \\
2018 & 9 & 29 & 183 & 2.9 & 18.8 \\
2019 & 14 & 35 & 289 & 13.1 \\
2020 & 19 & 55 & 15.2 & 15 \\
\hline
\end{tabular}

TP total number of publications; AU total number of authors; PG page count.

We found that the research on the mortality risk of MSE is increasing because entrepreneurship is a global trend, as it is considered a driver for economic growth $[4,39,40]$ and a contributor to the creation of jobs and innovations [2]. Therefore, the management of MSEs has gained importance at the social, governmental, business, and academic levels [6].

The most productive periodicals were Procedia-Economics and Finance, with seven publications, and Procedia-Social and Behavioral Sciences, with four publications, representing $6.6 \%$ and $3.7 \%$ of the total, respectively (Table 2 ). Of the ten most productive journals, six were from the United Kingdom (18 publications) and two were from Brazil (4 publications).

To classify the articles according to the type of research, the division of theory construction research into analytical and empirical was used [41]. Analytical research uses deductive techniques to find results, while empirical research uses induction and empiricism to arrive at theories. The two types of research are subdivided into three categories each. Thus, there are six types of research, with different methodologies, and each one aims to develop a theory.

Analytical research was divided into analytical conceptual research, analytical mathematical research, and analytical statistical research. The different categories are distinguished in the use of logic and mathematics for the construction of a theory. The conceptual research aims to introduce new concepts to existing problems where the methodology used is logic. Analytical mathematical research develops mathematical relationships between variables and studies the behavior of models in different situations. Analytical statistical research integrates mathematical logic models and statistical models, providing models integrated into a single theory, which will later be used for future empirical statistical tests. 
Table 2. The ten most productive journals on the topic of this review.

\begin{tabular}{cccc}
\hline $\begin{array}{c}\text { Top } \\
\mathbf{1 0}\end{array}$ & Journals & TP & Country \\
\hline 1 & Procedia Economics and Finance & 7 & the Netherlands \\
2 & Procedia-Social and Behavioral Sciences & 4 & United Kingdom \\
3 & Cogent Business \& Management & 3 & United Kingdom \\
4 & Journal of Small Business \& Entrepreneurship & 3 & United Kingdom \\
5 & Journal of Small Business and Enterprise Development & 3 & United Kingdom \\
6 & World Development & 3 & United Kingdom \\
7 & African Journal of Business Management & 2.8 & 2.8 \\
8 & Brazilian Journal of Operations \& Production Management & 2 & South Africa \\
9 & Information Technology for Development & 2 & Brazil \\
10 & Innovation \& Management Review & 2 & United Kingdom \\
\hline
\end{tabular}

TP total number of publications, \% percentage of publications in the dataset.

Empirical research was classified into empirical experimental research, case study, and empirical statistical research. Empirical experimental research seeks to examine and monitor the relationship between variables to determine their effect on certain dependent variables. This subcategory is known as 'field experiment'. Empirical case studies, as reviewed here, consist of in-depth research carried out within a limited number of organizations. This method uses data to develop a theory while the conceptual method uses deduction to develop theories. Empirical statistical research, as reviewed here, verifies theoretical relationships in large samples of real businesses with statistical analyses.

The results in Table 3 showed that empirical statistical research was the type of method highlighted, present in 66 articles $(62.3 \%)$. The most used methods were analytical conceptual research, described in twenty articles (18.8\%), and empirical case study, portrayed in sixteen articles $(15.1 \%)$. The methods that had the least applicability were analytical statistical research (three articles) and empirical experimental research (one article), representing $2.8 \%$ and $0.9 \%$, respectively. Empirical research totaled eighty-three articles $(78.3 \%)$, and sixty-six of those used a statistical approach. Analytical research was present in twenty-three articles (21.6\%), with twenty of those displaying a conceptual approach. No article used analytical mathematical research.

Table 3. The evolution of research on business mortality by type of research method.

\begin{tabular}{|c|c|c|c|c|c|c|c|c|c|c|c|c|c|c|c|c|c|c|c|c|c|c|c|}
\hline & & ఫ్రి & ఫ్రి & ઠิ & ర్లి & ఫ્సે & 옹 & ఫ̊ํి & ఫิે & ஓ्ণ & ஓे & 올 & 궁 & 궁 & 号 & 茫 & 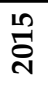 & $\begin{array}{l}0 \\
\text { 워 }\end{array}$ & 웟 & $\stackrel{\infty}{\stackrel{\infty}{\sim}}$ & 월 & 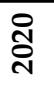 & ণ্ণ \\
\hline \multirow{3}{*}{ 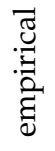 } & experimental & & & & & & & & & & & & & 1 & & & & & & & & & \\
\hline & case study & & & & & & & & & & & 1 & & 1 & & 1 & 1 & 1 & & 1 & 4 & 4 & 2 \\
\hline & statistical & & & & 1 & & & & & 2 & 1 & 1 & 4 & 5 & & & 5 & 9 & 8 & 8 & 9 & 11 & 2 \\
\hline \multirow{3}{*}{ 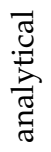 } & statistical & & & & & & & & & & & & & & & & & 1 & 1 & & & 1 & \\
\hline & mathematical & & & & & & & & & & & & & & & & & & & & & & \\
\hline & conceptual & 1 & & 1 & & & 2 & & & & & 2 & 1 & 1 & & 4 & & & 1 & 1 & 1 & 3 & 2 \\
\hline
\end{tabular}

Analytical conceptual research studies were dedicated to exploring new concepts and developing theories about entrepreneurship [42], characteristics and skills of the entrepreneur $[5,8,43,44]$, company characteristics, management strategies $[43,45]$, and the influence of the external environment on MSEs [8]. The use of technologies, such as the Internet of Things and e-business, was cited to improve processes [44,46,47]. Marketing practices [48], public policies [8,26], and innovation in products and processes [49] helped in the growth of MSEs. 
Machado and Espinha [11] tried to better understand why MSEs fail and suggested three risk categories: entrepreneur, company, and external environment. Abor and Quartey [4] described the characteristics, contributions, and restrictions that exist for MSEs.

Recent research has presented the challenges and impact that were generated in MSEs during the COVID pandemic [26,50-53]. In his study, Nogueira [53] elaborated a proposal for emergency government assistance for the MSE segment, besides making a brief analysis of the measures adopted by the government. Akuoko et al. [26] discussed the need for regulations for informal MSEs. The final product also showed systematic review studies [40,54]. Chikweche and Bressan [40] addressed the implementation of organizational learning, which addressed the complexities and dynamism of the operating environment. Donner and Escobari [54] reviewed the use of mobile technology in MSE, detailing discoveries and changes in internal and external processes.

In the analytical statistical research, three studies were found that sought to integrate the mathematical and statistical models into a single and larger model. Khan and Shah [55] made a comparison between trained and untrained entrepreneurs to assess the effectiveness of an entrepreneurship development program and the effect on the entrepreneur's performance. Nosratabadi [56] analyzed the effect of a loan program to Iranian companies on unemployment between 2005 and 2010, based on two different methods of assessing the causal effects. Duda et al. [57] identified the existing barriers to innovation for Polish MSEs.

In the empirical case study, in-depth research was presented and developed in a small number of companies. Studies were developed on the factors that determined the decisions of German MSEs on the adoption of renewable sources [58], obstacles to accessing finance [59], management problems faced by small businesses in the Philippines [60], and the civil construction sector in the city of Jundiaí [61]. Ratnaningtyas et al. [62] evaluated the entrepreneurial capacity in the fish industry in Indonesia under three dimensions: entrepreneurial, technical, and management skills. Alshami et al. [63] verified what affects sustainability in companies managed by women. Alonso and Kok [18] examined how European MSE owners and managers perceive the success and future of their businesses through semi-structured interviews. Lukiyanto and Wijayaningtyas [64] analyzed the perception of sporting event owners regarding the difficulty of capital in the business, and Galvão et al. [65] mapped the process of time and resources to understand the constraints and bottlenecks of a microcompanie of PET brooms. Liberman-Yaconi et al. [13] investigated how Australian microcompanies in the IT field make strategic decisions, and Pozo et al. [66] analyzed innovation and applied technology in the context of a sustainable production chain of SME manufacturing metal frames. Rascón and Velázquez [6] investigated the factors that put the continuity of Mexican and Colombian microenterprises at risk. Bressan and Pedrini [67] examined sustainability-oriented innovation practices among MSEs operating in the tourism and hospitality sector.

Other investigations verified the performance of organizations during and after the pandemic. The study of Amankwah-Amoah [68] was conducted on two Asian airlines and proposed a four-stage approach to renewing underperforming organizations. Smart et al. [69] investigated two hotels in Oklahoma, and Bartik et al. [14] analyzed how small businesses faced major challenges during the pandemic.

Empirical experimental research was evidenced in the study by Mano et al. [70], who examined the performance of African MSE clusters. The randomized experimental study was carried out in Ghana and showed that external factors and limited commercial experience were barriers found in this segment.

Empirical statistical research was carried out on large samples using statistical techniques. The studies in this category were applied in private business and investigated the characteristics of companies and entrepreneurs [12,71-75], customer relations [76], success factors $[27,77,78]$, determinants of business survival $[9,23,77-79]$, 
factors that contributed to failure [15-17,80-82], and factors related to the performance of MSEs [19,24,83-86]. Organizational difficulties in management involving finance [21,87-92], environmental sector [93-95], quality systems [96], supply chain [97], innovation [3,98-107], and competitive strategies [7,20,22,95,108-115] were identified. Some studies verified measures of resilience and status of MSEs during the COVID pandemic $[116,117]$.

The techniques for data analysis were: multiple linear regression $[3,7,21,24,84,89,95-97,103]$, factor analysis $[22,74,95,97,98,102,109,111,117,118], t$ test $[19,77,97,101,102]$, correlation $[24,89,97]$, analysis of main components [25], analysis of variance [97], descriptive statistics [15,89,104,107], SWOT Analysis [77], logistic regression [92,93,101], cluster analysis [98], structural equation modeling $[86,102,109]$, and survival analysis $[9,99]$.

\subsection{Authors, Highlighted Publications, and Keywords}

Authors who contributed scientifically to the area were from Australia, Ghana, India, and Indonesia (Table 4). The authors with the highest h-indexes were two researchers from Australia and one from India. They quantified the productivity and impact of scholars, based on the most cited articles. In this paper, the h-index from Scopus (update in November 2021) was used.

Of the total number of authors who published on the topic, eighty-seven authors had two publications and one hundred seventy-nine researchers had 1 publication.

Table 4. The ten main authors and the most published articles on the topic.

\begin{tabular}{ccccc}
\hline Top 10 & Author & TP & Country & h-Index \\
\hline 1 & Alessandro Bressan & 7 & Australia & 10 \\
2 & Ahmed Agyapong & 5 & Ghana & 7 \\
3 & Matthijs Den Besten & 4 & France & 8 \\
4 & Abel Duarte Alonso & 3 & Australia & 21 \\
5 & Abhishek Tripathi & 2 & India & 11 \\
6 & Acip Sutardi & 2 & Indonesia & 2 \\
7 & Aleksandra Gasior & 2 & Poland & 2 \\
8 & Alhassan Iddrisu & 2 & Ghana & 2 \\
9 & Anton Mulyono Azis & 2 & Indonesia & 2 \\
10 & Bhausaheb R. Londhe & 2 & India & 3 \\
\hline
\end{tabular}

TP total number of publications.

The top ten most-cited authors according to Scopus data in November/2021, the title of their publication, and the research method used are presented in Table 5. Of the ten most cited publications, four used the conceptual research method, and Abor and Quartey [4] and He and Harris [52] stood out for having the highest number of citations in the literature. Of the most cited authors, three published empirical statistical studies, two published empirical case studies, and one author published an empirical experimental article (Table 5).

Based on the keywords of the selected articles, a word cloud was created, which served to identify the direction of the studies that were published on the subject (Figure 4). Out of a total of 425 keywords, 115 elements were presented in at least two repetitions. The eigth words that stood out were: 'micro', 'business', 'innovation', 'management', 'entrepreneurship', 'performance', 'MSEs', and 'SMEs'. 'MSEs' was the acronym used for micro and small businesses, and 'SMEs' was used for small and medium businesses. These were the most studied topics in this selection and the study period. 


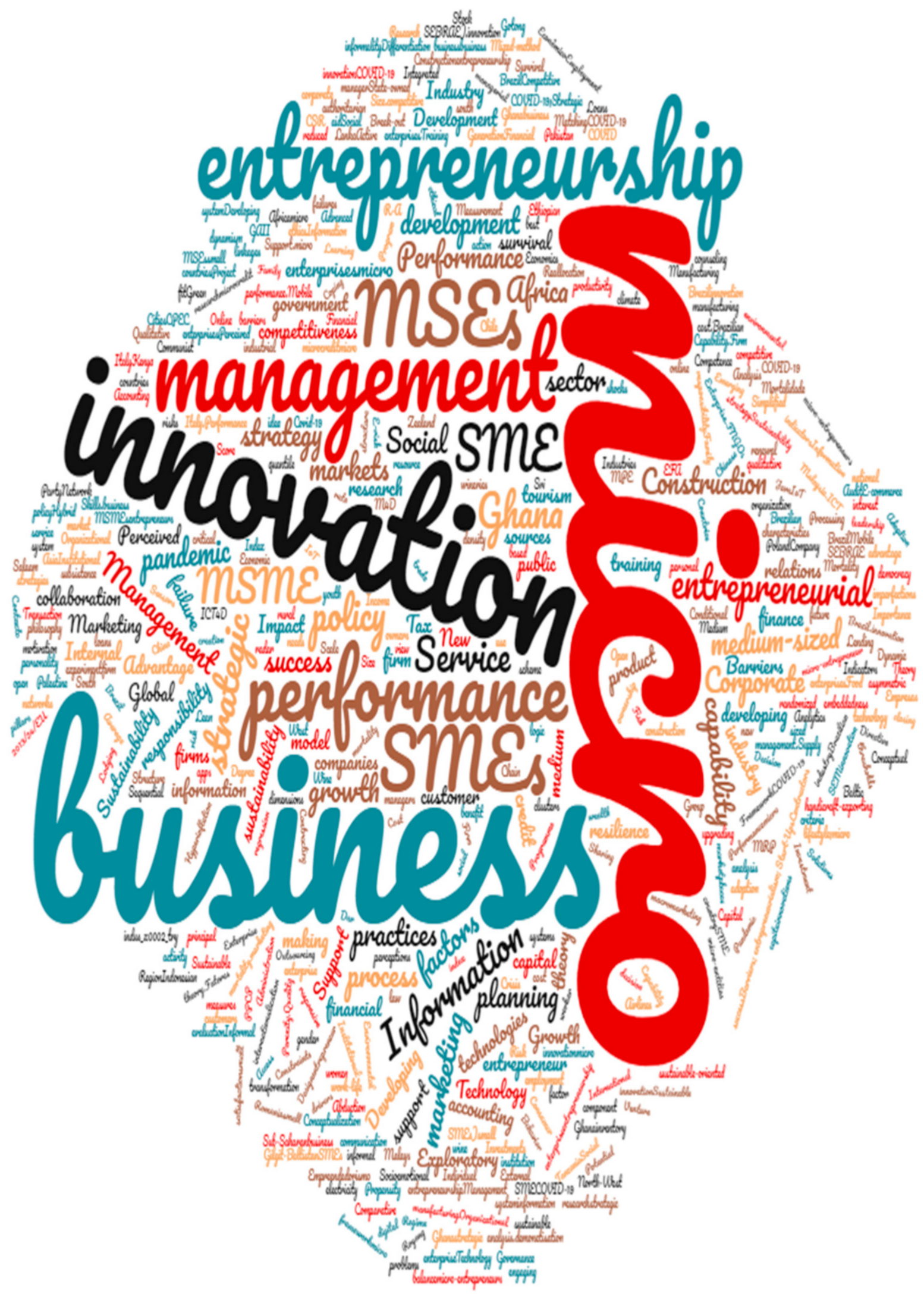

Figure 4. The keywords of the analyzed articles that stood out on the theme of business mortality in MSE. 
Table 5. Highlighted publications and citations.

\begin{tabular}{|c|c|c|c|c|}
\hline Year & Author(s) & Publication Title & Research Method & Citations \\
\hline 2010 & Abor and Quartey & $\begin{array}{l}\text { Issues in SME development in Ghana and } \\
\text { South Africa }\end{array}$ & $\begin{array}{l}\text { Analytical } \\
\text { Conceptual }\end{array}$ & 326 \\
\hline 2020 & He and Harris & $\begin{array}{c}\text { The impact of COVID-19 pandemic on } \\
\text { corporate social responsibility and } \\
\text { marketing philosophy }\end{array}$ & $\begin{array}{l}\text { Analytical } \\
\text { Conceptual }\end{array}$ & 213 \\
\hline 2012 & Cruz et al. & $\begin{array}{l}\text { Does family employment enhance MSEs } \\
\text { performance?: Integrating socioemotional } \\
\text { wealth and family embeddedness perspectives }\end{array}$ & Empirical Statistical & 178 \\
\hline 2020 & Bartik et al. & $\begin{array}{l}\text { The impact of COVID-19 on small business } \\
\text { outcomes and expectations }\end{array}$ & Empirical Case study & 168 \\
\hline 2011 & Gunasekaran et al. & $\begin{array}{l}\text { Resilience and competitiveness of small and } \\
\text { medium-size enterprises: an empirical research }\end{array}$ & Empirical Statistical & 156 \\
\hline 2010 & Donner and Escobari & $\begin{array}{l}\text { A review of evidence on mobile use by micro } \\
\text { and small enterprises in developing countries }\end{array}$ & $\begin{array}{l}\text { Analytical } \\
\text { Conceptual }\end{array}$ & 108 \\
\hline 2012 & Mano et al. & $\begin{array}{c}\text { How can micro and small enterprises in } \\
\text { Sub-Saharan Africa become more productive? } \\
\text { The impacts of experimental basic } \\
\text { managerial training }\end{array}$ & Empirical Experimental & 86 \\
\hline 2015 & Rahayu and Day & $\begin{array}{c}\text { Determinant factors of e-commerce adoption by } \\
\text { SMEs in developing country: evidence } \\
\text { from Indonesia }\end{array}$ & Empirical Statistical & 76 \\
\hline 2010 & Liberman-Yaconi et al. & $\begin{array}{l}\text { Toward a model of understanding strategic } \\
\text { decision-making in microfirms: exploring the } \\
\text { Australian information technology sector }\end{array}$ & Empirical Case study & 72 \\
\hline 2000 & Fielden et al. & $\begin{array}{l}\text { Barriers encountered during micro and small } \\
\text { business start-up in North-West England }\end{array}$ & $\begin{array}{l}\text { Analytical } \\
\text { Conceptual }\end{array}$ & 47 \\
\hline
\end{tabular}

\subsection{Mortality Risk Factors in MSEs and the State of the Art on the Topic}

The results showed 36 risk factors for mortality. These factors are presented in five categories: entrepreneur characteristics risks, business management risks, risks linked to lack of innovation in the business, risks associated with customers' difficulties, and risks due to the influence of external factors.

\subsubsection{Entrepreneur Characteristics Risks}

The risk factors in this category were related to the profile, technical knowledge, skills, abilities, and experiences of the entrepreneur (Table 6). The entrepreneur's characteristics correspond to determination, objectivity, commitment, creativity [15,16,25], and the entrepreneur's profile, includes age, education, income, gender, and so on $[7,16,24,25]$. Regarding the gender of the entrepreneur, there is evidence that there is a positive effect between performance and the female gender in MSEs [71,73,80,83]. Chirwa [71] reveals that women are increasingly participating as MSE entrepreneurs in developing countries. The author adds that although there are no significant differences in profit margins, womenowned MSEs grow faster in terms of employment compared to male-led companies. This is partly due to access to credit at microfinance institutions that target women entrepreneurs and due to the impact of education. 
Table 6. Mortality risk factors related to the entrepreneur.

\begin{tabular}{|c|c|c|c|}
\hline $\begin{array}{c}\text { Risk } \\
\text { Category }\end{array}$ & Definition & Risk Factors & Source \\
\hline \multirow{6}{*}{$\begin{array}{c}\text { Entrepreneur } \\
\text { characteristics risks }\end{array}$} & \multirow{6}{*}{$\begin{array}{l}\text { It refers to the } \\
\text { entrepreneur's profile, } \\
\text { technical knowledge, } \\
\text { skills, abilities, } \\
\text { and experiences. }\end{array}$} & Profile & {$[7,8,16,24,25,27,42,71,73,79,83]$} \\
\hline & & Personal characteristics & {$[15,16,25,48,62,85]$} \\
\hline & & Lack of capacity building and training & {$[6,17,24,55,61,70,74]$} \\
\hline & & $\begin{array}{l}\text { Lack of technical } \\
\text { knowledge }\end{array}$ & {$[24-26,80,87]$} \\
\hline & & $\begin{array}{l}\text { Management skills } \\
\text { and competences }\end{array}$ & {$[15-17,24-26,42,43,48,60-62,85]$} \\
\hline & & $\begin{array}{l}\text { Lack of experience in } \\
\text { business management }\end{array}$ & {$[5,15,16,23-25]$} \\
\hline
\end{tabular}

Some authors highlighted the importance of training [24,55,70,74], capacity building [61], and technical knowledge [24,26,55]. An increase in qualifications, both academic and professional, reduces the possibility of company bankruptcy, as well as being a resource that creates competitive advantages for MSEs [25,26,119].

The importance of the entrepreneur having previous experience in business management was also mentioned [5,23-25].

Another important factor was the development of managerial skills and abilities [15-17,43]. Indicators of entrepreneurial skills include persistence, proactivity, entrepreneurial behavior [24], ability to take risks, orientation to change, commitment, leadership, motivation [25], good communication, critical capacity, and perception of the internal and external environment [62].

Ratnaningtyas et al. [62] pointed out problems of communication. These problems involve the relationships between customers, suppliers, and employees $[48,61,85]$.

\subsubsection{Business Management Risks}

This category underscores a company's management problems in everyday actions (Table 7). Among the factors listed were the difficulties in economic and financial management, such as the lack of cash flow control, the lack of financial results analysis, the difficulty in separating the assets, rights, and obligations of the individuals and legal entities, high operating costs, and lack of investment $[39,77,80]$. The problems of working capital for operationalization $[15,25]$, debts, and insufficient income $[6,80,87]$ were also present.

The problems regarding the lack of accounting management $[24,25,39]$ and lack of legal guidance [25] were cited. Problems with inventory management, which are related to the discrepancy between the real and theoretical [61] and the purchase of lots, optimize the gains resulting from the volumes purchased without causing an imbalance in the financial level [86]. In logistics, the problems of contracts with customers for deliveries were pointed out, followed by the definition of more economical routes and the difficulty of assuring the quality and balance of products during transport [61].

In purchasing management, the difficulty was related to minimum purchase lots, as large suppliers often impose this condition [61]. In strategic management, the volatility of the sector proved to be a difficulty due to economic changes [39]. It is important to pay attention to differentiation strategies, with an emphasis on management quality, innovation, business marketing, and cost leadership [3,82].

The problems with operations management proved to be a challenge regarding quality management [39,60], human resources [3,39,61], and marketing [3,39,82]. Anholon et al. [61] added the problems with sales, where difficulties are found in setting goals, managing and monitoring the activities of the sales teams, and achieving customer loyalty. 
Table 7. Mortality risk factors related to management.

\begin{tabular}{|c|c|c|c|}
\hline Risk Category & Definition & Risk Factors & Source \\
\hline \multirow{18}{*}{$\begin{array}{c}\text { Business } \\
\text { management risks }\end{array}$} & \multirow{18}{*}{$\begin{array}{l}\text { It represents the } \\
\text { company's management } \\
\text { problems in } \\
\text { everyday actions. }\end{array}$} & Problems in economic and financial management & {$[4,6,8,12,15,17,25,39,40,49,61,64,75,80,84,87,91,120,121]$} \\
\hline & & Problems in accounting management & {$[24,25,39,74,87]$} \\
\hline & & Lack of legal guidance & [25] \\
\hline & & Sales management issues & {$[8,17,27,61,73]$} \\
\hline & & Inventory management problems & {$[61,86]$} \\
\hline & & Problems in logistics management & {$[61]$} \\
\hline & & Quality management problems & {$[3,13,39,60,82]$} \\
\hline & & Problems in purchasing management & [61] \\
\hline & & Problems in strategic management & {$[3,13,39,61,115]$} \\
\hline & & Operations management problems & {$[39,60]$} \\
\hline & & Problems in personnel management & {$[3,39,61,85]$} \\
\hline & & Problems in marketing management & {$[3,23,39,60,82]$} \\
\hline & & Lack of strategic planning & {$[3,16,25,27,62,65,108]$} \\
\hline & & Difficulty in obtaining credit & {$[5,20,21,23-25,43,45,49,56,59,60,72,88-90,92,101]$} \\
\hline & & High competition & {$[5,16]$} \\
\hline & & Failures, underutilization, and lack of information & {$[24,44,60,84,97,110,114]$} \\
\hline & & $\begin{array}{l}\text { Lack of strategic alliances and } \\
\text { cooperation networks }\end{array}$ & {$[5,18,19,23,77,100]$} \\
\hline & & Lack of advertising & {$[49,61]$} \\
\hline
\end{tabular}

The absence of strategic planning and the existence of failures were incorporated into management problems as elements of mortality risk [3,16,108].

Another factor was the difficulty in accessing financial services for loans and financing $[20,21,23,24]$. Another problem encountered by Fielden et al. [49] was obtaining credit from suppliers.

The difficulty in obtaining credit, which occurs due to the lack of working capital for the development of operations, was also mentioned. Restrictions are the main barriers to accessing credit when considering the company owner and the characteristics of the company (lack of guarantees and arrears) [92]. Other obstacles were the financial cost of using these services, with high-interest rates in operations and bureaucracy that impact growth, job creation, and the development of MSEs [21,56,59]. In this regard, some countries have special credit lines for SMEs because they understand the importance of this sector for economic development. These credit lines have lower interest rates and fees, longer grace periods, and quick analysis, and can be used for investments or working capital.

Competition must be constantly observed by the entrepreneur $[5,16]$. Knowing the strengths and weaknesses of competitors is important for strategic planning [5].

Flaws and lack of information are other problems with informal and personal sources [24,60], while information based on the market is often ignored [110]. According to Vera [60], this results in structural and institutional barriers and demonstrates the limited ability of entrepreneurs to evaluate the environment and access specific information. Woida [114] adds that information is also underutilized, and many customers and external reports are not used to improve or innovate products, services, and processes. Besides, if companies had information on what, when, and to whom to sell their products/services, it would help not only in the survival of businesses but also in their performance [44,97].

It was identified that a lack of commercial networks between entrepreneurs, the government, financial institutions, and other business associations has a negative influence on the survival of companies [5,23]. Cooperation and the formation of strategic alliances are essential, becoming a determinant factor between success and failure [18,19,77]. Companies involved in inter-organizational cooperation present an exchange of knowledge between agents (suppliers, producers, consumers, industry associations, cooperatives, event orga- 
nizers, festivals, fairs, and tourism), the community, and private information to expand learning $[77,100]$.

Lack of understanding of advertising (when and how it should be undertaken) was also seen as a problem, and the unavailability of financial resources for this purpose affects business continuity [61].

It is common for entrepreneurs not to view advertising and advertising expenditures as an investment, and therefore to place it as a low priority. Anholon et al. [61] added that companies often have difficulties in defining the exact customer to be reached by the advertising.

\subsubsection{Risks Linked to Lack of Innovation in Business}

The factors in this category were related to the lack of investment in innovation for the development of products, services, and processes in MSEs (Table 8).

Table 8. Mortality risk factors related to innovation.

\begin{tabular}{|c|c|c|c|}
\hline Risk Category & Definition & Risk Factors & Source \\
\hline \multirow{4}{*}{$\begin{array}{l}\text { Risks linked to lack } \\
\text { of innovation in } \\
\text { the business }\end{array}$} & \multirow{4}{*}{$\begin{array}{l}\text { It refers to the lack of } \\
\text { investment in } \\
\text { innovation for the } \\
\text { development of } \\
\text { products, services, } \\
\text { and processes } \\
\text { in companies. }\end{array}$} & $\begin{array}{l}\text { Lack of innovation in the development } \\
\text { of products, services, and processes }\end{array}$ & $\begin{array}{c}{[3,16,25,39,57,58,62,66,76,96,98,99,} \\
102-104,107,113,118]\end{array}$ \\
\hline & & $\begin{array}{c}\text { Lack } \\
\text { of technologies }\end{array}$ & {$[22,23,27,46-48,54,60,78,106,109,111,118]$} \\
\hline & & $\begin{array}{l}\text { Lack of sustainable environmental } \\
\text { policies and practices }\end{array}$ & {$[63,67,93,94]$} \\
\hline & & $\begin{array}{l}\text { Absence of corporate } \\
\text { social responsibility }\end{array}$ & [112] \\
\hline
\end{tabular}

A lack of investment in innovation was considered a relevant factor in the risk of mortality in MSEs [3,16,25]. Pozo et al. [66] found that one of the requirements to obtain results was to optimize available resources, which would lead to more investments in innovation for the production of goods and provision of services. Productivity improvement comes from investment in technology, incorporated into the production structure and the employee training and education process [66].

Innovative organizations have a higher survival rate when they present a diversified portfolio $[99,102,105]$. De Paulla and Hamza [96] pointed out that any organization that seeks to innovate must be proactive, overcome market demands, and manage the quality of products and services. The company's ability to incorporate external and internal knowledge, tacit or explicit, is an asset for a successful strategy $[57,103,104,107]$. For Vorkapić et al. [113], sources of ideas for the development of new products and services can be competitors, customers, employees, participation in fairs, or exhibitions.

It was identified that the use of technology and e-commerce strategies was an advantage for MSEs [23,78]. For Corner et al. [47] the use of an electronic website and its resources, such as product information, company data, sales, payments, and online purchases, add value to products and services.

The use of telephony, mobile applications, and social networks, strongly influence the ability to seek new business opportunities, in addition to expanding the communication, marketing, and search processes for existing information [22,48,106]. Donner and Escobari [54] mentioned that MSEs become competitive to serve a society that is increasingly demanding and operating in different virtual channels, but for this to happen, the barriers of lack of knowledge, trust, and credibility must be broken by organizations.

Another point that had a positive relationship with an organization's survival was the investment in information technology (IT) [75,109]. Quelhas [111] added that a large number of micro and small entrepreneurs are not familiar with the potential of IT and therefore have doubts about how beneficial IT investments are for an enterprise. 
Another important element was the lack of incentives for sustainable environmental policies and practices of MSEs. Due to the demands of the community and the market, the adoption of these practices, combined with innovation and applied in strategic actions, results in benefits for companies as they seek to minimize their socio-environmental impacts $[67,93,94]$. Alshami et al. [63] added that lack of product diversity and little flexibility in the implementation process are factors that affect the practice of sustainability.

With the adoption of environmental practices, companies revealed their commitment and corporate social responsibility (CSR) to society, causing a positive impact in the field of their activity [112].

In the study by Skypalová et al. [112], it was found that there is a correlation between company size, awareness, commitment, and CSR activities. With this, it was verified that MSEs have little knowledge, and consequently less involvement in the three pillars of CSR (social, economic, and environmental). The social pillar refers to activities carried out in regard to ethics and organizational culture, health, safety, training, qualification and education of employees, diversity in the workplace, and equal opportunities. The economic pillar concerns the non-acceptance of corruption, fraud, and unfair competition, good relationships within the supply chain, loyalty to the company, and transparency in the company's activities and results. In the environmental pillar, there are the activities of recycling, reduction, use and management of waste, and reduction in the use of materials, energy, and water [112].

The adoption of CSR practices reveals a commitment to society and the company's employees, causing a positive impact on its field of activity [112]. Porter and Kramer [119] evaluate CSR and add the concept of 'Created Share Value' (CSV). The authors reveal that shared value is fundamental for the innovation and growth of organizations. This creates social benefits and a connection between the company's success and the community.

\subsubsection{Risks Associated with Customer Difficulties}

Difficulties in attracting and retaining customers were found in the literature $[15,16,49,61]$ (Table 9).

Customers are the key to the success of any business. Every enterprise, before opening, should know its target audience and discover their needs, preferences, and perceptions. Furthermore, retaining existing customers is as important as winning new customers. This retention is linked to knowing the competition's values and exceeding customers' expectations with regard to the quality of products and services offered [61].

Table 9. Mortality risk factors related to customers.

\begin{tabular}{|c|c|c|c|}
\hline $\begin{array}{c}\text { Risk } \\
\text { Category }\end{array}$ & Definition & Risk Factors & Source \\
\hline \multirow{4}{*}{$\begin{array}{l}\text { Risks associated with } \\
\text { customer difficulties }\end{array}$} & \multirow{4}{*}{$\begin{array}{l}\text { It represents the difficulty for MSEs in } \\
\text { winning new customers and retaining } \\
\text { existing ones. }\end{array}$} & $\begin{array}{c}\text { Difficulty in } \\
\text { winning customers }\end{array}$ & {$[15,16]$} \\
\hline & & Difficulties in retaining customers & {$[16,49,61]$} \\
\hline & & Inadequate location & {$[15,24,61,92]$} \\
\hline & & $\begin{array}{l}\text { Lack of adequacy and accessibility in } \\
\text { the infrastructure }\end{array}$ & {$[24,81,92]$} \\
\hline
\end{tabular}

Another element was the location of the company, which must be accessible for the flow of customers [15,24,92]. Anholon et al. [61] highlighted two points that must be observed before defining the location of a business: the target audience, which consists of potential consumers and their preferences, and the competition, who may indicate what can be improved or updated. The adequacy and accessibility of infrastructure at the commercial point of the establishment are of paramount importance [24,81,92]. 


\subsubsection{Risks Due to the Influence of External Factors}

External aspects are the problems that the entrepreneur has no control over (Table 10), such as the economic and financial crises of a country, the high tax burden, the lack of public policies to support specific sectors, and disruptive forces.

Table 10. Mortality risk factors related to external factors.

\begin{tabular}{|c|c|c|c|}
\hline $\begin{array}{c}\text { Risk } \\
\text { Category }\end{array}$ & Definition & Risk Factors & Source \\
\hline \multirow{4}{*}{$\begin{array}{l}\text { Risks due to the influence of } \\
\text { external factors }\end{array}$} & \multirow{4}{*}{$\begin{array}{l}\text { It refers to externalities, that is, } \\
\text { problems over which the } \\
\text { entrepreneur has no control. }\end{array}$} & Economic and financial crises & {$[9,15,17,27,61,80,84]$} \\
\hline & & High tax burden & {$[15,17,61,80,84]$} \\
\hline & & Lack of public policies & {$[5,8,27]$} \\
\hline & & Disruptive forces & {$[14,26,50-53,68,69,116,117]$} \\
\hline
\end{tabular}

The effect of disruptive forces refer to recessions, wars, disasters, and epidemics, such as World War I (1914-1918), World War II (1939-1945), the Great Depression (1929-1939), the Global Financial Crisis (2007-2009), and the COVID pandemic (starting in December 2019), which had major impacts on organizations [69]. The COVID pandemic was the most prominent external factor in recent times and it is a new situation with an unknown time duration [52]. It appeared in December 2019 and, as a result of this scenario, some countries had to close their borders and many companies were forced to suspend their activities. This context resulted in a worldwide economic crisis, and consequently, individuals and organizations were affected, mainly micro and small entrepreneurs.

According to Smart et al. [69], the disruptive effect of the pandemic has gained the attention of researchers to investigate the types of changes in demand and strategies to face the pandemic crisis in all aspects. It is added that the crisis also had an impact on financial markets, and one of the problems faced by companies was the lack of capital to modify or adapt their business model [50]. Small businesses are financially fragile, and many of these ventures had little money available when the pandemic started. Thus, it was necessary to cut expenses, contract other debts, or close down activities [14]. Alon et al. [51] mention that humanity is currently facing a humanitarian crisis, fear and uncertainty about the future, and a financial and economic crisis, with problems in both supply and demand. The other challenging crisis is the lack of world leaders to deal with the invisible problems [51].

With the emergence of this crisis, it became difficult to make plans due to the uncertainties and concerns that arose both in health and the economy [122]. However, depending on the type of sector, this crisis represents a business opportunity [51,69]. AmankwahAmoah et al. [68] point out that companies should use COVID as inspiration for innovation. These authors developed the 'CoviNovation', which highlights organizations' expected and unexpected innovations that originated during, or were accelerated by, the pandemic.

Regarding urgent governmental measures to combat the pandemic crisis, emergency funds were mentioned, which were established to serve small businesses, such as longer grace periods and reduced interest rates to help companies preserve jobs, supporting families against income reductions [123]. It was found that MSEs are seeking strategic actions to contain the risk of mortality through training, innovation, the development of new products or services, and the implementation of new technologies. Strategic positioning was important in this period for a company to continue competing in the market and benefiting its customers.

\section{Discussion}

The main objective of this research was to analyze the factors that contribute to the risk of mortality in MSE. In summary, it was found that studies on business mortality expanded from 2016 onwards (Figure 3). The published articles explore the themes of survival, failure, performance, and growth of MSEs. In the years 2019 and 2020, the number of publications grew. This is explained by the fact that entrepreneurship is a global trend, a driver of 
economic growth [1,4,39,40,121], and a contributor to job creation and innovation [2]. Thus, the management of MSEs gained importance at the social, governmental, business, and academic levels [6]. The increase in 2020 is also explained by the impact that the COVID pandemic had on MSEs, and thus, most of the works developed in the period were based on the effect that this crisis had on this segment. The disruptive effect of the pandemic has become the focus of many researchers, which examine the types of changes in demand and strategies for coping with the crisis [69].

In publications by type of research, evolution was observed over the last few years in empirical statistical research (Table 3). For the development of these surveys, questionnaires and statistical techniques were applied. The most frequently used techniques were linear regression and factor analysis. Păunescu and Mátyus [117] explain that the use of factor analysis allows the identification of factors that explain the correlation within a set of observed mortality risk factors, while linear regression determines which variable has the greatest impact on mortality risk.

The case study methodology was evaluated in private companies (Table 3). The studies analyzed barriers and challenges in different industries and business sectors. Works were also carried out investigating the survival and success of these companies.

Analytical conceptual studies continue to progress in publications (Table 3). Discussions about the importance of MSEs for economic development where it operates were highlighted, and brought reflections on what contributes to the non-closure of these organizations. Roratto et al. [28] added the need to develop instruments that can reduce corporate mortality and create programs that incorporate accumulated theoretical and empirical knowledge. The results regarding the relationship between the dimensions and subdimensions that contribute to the mortality risk of MSEs were discussed in detail in the next sections.

The articles analyzed in this review included a total of 425 keywords. With this, a word cloud was created, and 8 words stood out as the most cited: 'micro', 'business', 'innovation', 'management', 'entrepreneurship', 'performance', 'MSEs', and 'SMEs'. It was found that the words 'innovation' and 'management', refer to two dimensions presented in this study, and stood out as representing the risk factors that had the highest total frequency (Appendix B). The word 'entrepreneurship' was also highlighted, confirming the direction of studies on this topic. Entrepreneurship is a global trend and, in this scenario, as MSEs represent most of the world's companies, this type of business emerges [6]. With this, it was verified that the risk factors related to innovation and business management deserve greater attention in the face of risks linked to the entrepreneur, customers and external factors. It should be noted that when innovation and management problems occur in MSEs, there is a tendency for business performance to be altered and impaired.

In the analyzed studies, 36 risk factors were identified, and the factor that stood out the most was that of problems in economic-financial management (Appendix B). Lack of working capital represents a financial problem for companies, which makes many companies seek financial institutions to obtain credit. Such problems influence the activities of all sectors, such as the development of innovative products, services, processes, and investment in technology. Findings in the existing literature show that there is still much to be explored about mortality in MSE, and Gupta and Tripathi [24] add that this topic has potential for future studies, as there are many factors that should be analyzed to improve the performance of MSEs and help the local economy, generating sufficient income.

In the literature, factors that increase the risk of mortality and those that reduce the risk can be found. Jamak et al. [5] investigated the factors that contribute to minimizing risks to business survival, and the factors that cause failures that can lead to mortality in MSEs. It was identified that education is one of the factors that reduces the risk. Entrepreneurship education maximizes growth rates in addition to increasing opportunities for developing new businesses, self-employment, creating new products, and being updated on market trends and management tools [5]. The authors add that business management training plays an important role in entrepreneurial effectiveness. Other important points that reduce 
the risk are: the use of marketing, which is a tool that helps in the investigation of consumer needs and desires and evaluates the competition, and financial literacy, which will provide information on how to negotiate lines of credit, manage payments and making financial decisions [5]. The literature also points out that the key to minimizing business failures includes training in technical assistance, good communication and the formulation of objectives and goals to be achieved [5]. The implementation of information technology is another factor that reduces risk, as it enables the growth of MSEs. The important thing in this investment is to think about how operations will be impacted, optimizing processes and activities [118].

On the other hand, the factors that increase mortality rates, according to the literature, are: competition, which develops innovative products and often targets consumers in terms of price and promotions; lack of networking between companies, employees, government, customers, and financial institutions, among others, to gain visibility and achieve competitiveness, and lack of managerial skills to develop business plans, obtain and use resources efficiently, balance finances, and maintain follow-up and control of daily operations [5]. The external factors that have impacted and increased MSE mortality since the 1990s are: limited access to finance, corruption, precarious public services, high taxes, and government bureaucracy [84].

\section{Relationship between Dimensions and Subdimensions of Mortality Risks in MSEs}

The first dimension emphasized the risks linked to the entrepreneur, presented in Section 3.3.1. In this category, it was evidenced that training and increasing qualifications must be constant, as they allow the entrepreneur to be updated in their area of expertise, implementing new techniques in the company's operations to solve problems and make internal processes efficient. Training leads to technical knowledge, which helps the entrepreneur in decision-making based on knowledge and not on intuition. Entrepreneurship involves many challenges; thus, knowledge helps entrepreneurs face daily difficulties and perform their tasks with quality and efficiency.

Managerial practices are linked to experience in business management, which allows the entrepreneur to know and have control over what happens in the company, making it possible to detect bottlenecks, failures, and opportunities for improvement. The skills and abilities of the entrepreneur must be improved and expanded. These skills involve your characteristics attitudes, strengths and weaknesses, which can interfere with the company's performance. Skill development allows entrepreneurs to reach their goals and finish their projects in an expert manner.

The second dimension was associated with managing risks in the company, presented in Section 3.3.2. Many articles focused on identifying and analyzing problems related to the company's day-to-day activities, and therefore, every entrepreneur, before opening a company, should research the market, the target audience, and the competition in order to make good decisions. It is important to prepare a business plan for the company to develop and succeed. The business plan identifies the strengths, weaknesses, opportunities, and threats of a company, in addition to presenting and achieving its previous activities, objectives, and goals. Management covers all areas of the company and seeks to analyze and solve problems, organize finances, motivate employees, and control the internal environment. Many entrepreneurs are forced to close their establishments because they manage their companies based on the excitement of having a business, without knowing the environment in which they operate or being familiar with the requirements of management, marketing, sales, strategy, operations, and so on.

Another important point is the difficulty in obtaining credit, which occurs due to the lack of working capital that MSEs have for the development of operations. This results in a search for credit with financial institutions that charge high interest and fees. In obtaining credit, the business may face eligibility barriers, as the process is bureaucratic and often results in denial of credit due to the restrictions of the system (insufficient income, debt in arrears, lack of documents and guarantees, personal and business documents 
with restrictions, etc.). Some countries have special credit lines for MSEs because they understand the importance of this sector for economic development. These credit lines have lower interest rates and fees, longer grace periods, and quicker analysis, and can be used for investments or working capital.

The third dimension was innovation, presented in Section 3.3.3. Innovation, in many cases, is not applied in the organization due to a lack of tools for its implementation. Innovation adds value to the company's products/services, making them a competitive advantage. The use of technology results in benefits for the company and the customer. The companies that do not change in the face of technological advances will not be able to continue their activities. Environmental practices improve the company's image, in addition to minimizing the business's impact on the environment.

The fourth dimension was the customer, shown in Section 3.3.4. Findings show that in a globalized and competitive market, it is important that companies know their consumers in order to create bonds, interact and satisfy their needs. Competition is presented not only by physical establishments, but also by virtual ones, which is why it is essential to please the customer with differentiated products and/or services that fit their wishes. The customer is the bedrock to a company's growth. A dissatisfied customer can propagate negative comments about the company that are disseminated on social networks, by the media, and by direct contact, harming the company's image. To win and retain customers it is important to exceed their expectations, announcing a better price than the competition, offering innovative and quality products and/or services, providing good service, offering training for sales staff to better know their customers, products, and/or the services that are being commercialized, and it is also important to solve customer problems quickly and value old customers via discounts, loyalty programs, bonuses, etc.

The fifth dimension was external factors, presented in Section 3.3.5. Findings show that external factors influence the operations of the company. These factors demand changes in processes and quick and intelligent decision-making to minimize the effects of a crisis. External elements that interfere are high-interest rates, which can make it difficult to repay loans and financing, inflation, which increases the value of production inputs, and unemployment, which affects consumer demand for products and services. The importance of public policies to support small businesses and support the creation of ventures for socioeconomic development is highlighted.

The disruptive effects of the COVID pandemic revealed an unexpected and unknown situation, creating difficulties for future planning due to the uncertainties that arose. However, these uncertainties and threats must be considered by managers in order to take advantage of business opportunities, and for that, strategic positioning is necessary, both for micro and small businesses, as well as for medium and large enterprises. In sum, the classification of these dimensions allowed the development of a conceptual model aimed at assessing the risk of mortality in MSEs. The model consolidated the results obtained and allowed for an understanding of the interdependence between the factors.

\section{Main Dimensions and Subdimensions}

The dimensions that stood out for their number of subdimensions (risk factors) were: management, entrepreneur, and innovation (Appendix B).

In the entrepreneur dimension, the subdimension with the highest frequency of citations was 'management skills and abilities', and in management it was 'problems in economic and financial management'. In innovation, 'the lack of innovation in the development of products, services, and processes' was most cited, while in customers, 'inadequate location' appeared most frequently, and finally, in external factors, the 'disruptive forces' were the most cited risk factor (Table 11). 
Table 11. Classification and citation frequency of mortality risk factors in MSE.

\begin{tabular}{lcc}
\hline Dimensions & Subdimensions & Frequency \\
\hline Entrepreneur & Management skills and competences & $5.4 \%$ \\
Entrepreneur & Profile & $5.0 \%$ \\
Management & Problems in economic and financial management & $8.6 \%$ \\
Management & Difficulty in obtaining credit & $8.2 \%$ \\
Innovation & Lack of innovation in the development of products, services, and processes & $8.2 \%$ \\
Innovation & Lack of technologies & $5.9 \%$ \\
Customers & Inadequate location & $1.8 \%$ \\
Customers & Difficulties in retaining customers & $1.3 \%$ \\
Customers & Lack of adequacy and accessibility in the infrastructure & $1.3 \%$ \\
External Factors & Disruptive forces & $5.0 \%$ \\
External Factors & Economic and financial crises & $3.1 \%$ \\
\hline
\end{tabular}

It was found that MSE managers should consider all identified subdimensions, but it is essential to pay attention to the subdimensions classified in the entrepreneur, management, and innovation dimensions (Table 11). In the entrepreneurial dimension, the importance of improving skills and competencies was observed, which reflects on the company's productivity. In the management dimension, the entrepreneur must know all the necessary and available tools for good business performance. In innovation, it was found that many companies do not innovate in technology, products, services, and processes, due to a lack of knowledge about the available tools and also because they are not open to change.

The subdimensions that appeared most frequently, in general, were: 'problems in economic-financial management', 'difficulty in obtaining credit', and 'lack of innovation in the development of products, services and, processes' (Table 11). These factors fall into two categories that stand out, namely: innovation and management.

The high percentage in the subdimension associated with innovation showed that entrepreneurs should invest in their business, in tools that help them to implement technologies and create new products, services, and organizational processes that add value. Innovation is a differential against the competition, and as a result, MSEs increase revenues, profits, conquer new markets, and reduce production costs.

The management-related subdimensions confirmed the lack of public policy incentives and support for MSEs, making the process of obtaining credit for working capital difficult. Entrepreneurs should better control their financial operations using mechanisms that help them in decision-making, such as financial planning, spreadsheets to monitor daily expenses, cash flow monitoring, cost and expense control, separation of the person's expenses on individual (entrepreneur) and legal entities (company), advising an accountant to solve economic-financial and accounting doubts, analysis of accounting reports, and so on.

\section{Conceptual Model of Mortality Risk in MSE}

Findings from thematic areas found in the literature review allowed the elaboration of a conceptual model for mortality risk analysis in MSEs (Figure 5). The functions of the model are (a) to contribute as a qualitative synthesis of the results obtained in the last 20 years of research on mortality risk in MSEs, and (b) to help entrepreneurs, governments, and educational institutions to develop support and development strategies. It is noteworthy that the model presented was not adopted or adapted from other authors, because a conceptual model for this purpose was not found in the literature review. The model was presented in its dimensions, subdimensions, and interrelationships.

The determining relationships were classified into five dimensions: external factors, entrepreneur, management, innovation, and customers (Figure 5). The dashed lines (A-D) show the relationship between external factors and the other dimensions. The dotted line $(E-G)$ shows the relationship between the entrepreneur and the other dimensions. The continuous line (H-J) shows the relationships between the customers, management and innovation dimensions (Figure 5). The analysis of these relationships between dimensions and their determinants allowed for in-depth knowledge about the mechanisms that con- 
tribute to the risk of mortality in MSEs. The model pointed out the direction of influence between dimensions. The direction of the arrows represented unidirectional (one way) or multidirectional (multiple directions) relationships. It was identified that external factors have a unidirectional causal relationship with the other dimensions (A, B, C, D) due to their impact on the activities and sectors of MSEs. External factors represent those risks that the entrepreneur has no control over, that are related to the external environment and that may occur unexpectedly, impacting the entrepreneur's actions, company management, customers' demand and behavior, and investments in innovation. Entrepreneurs are influenced by external factors that affect their decisions in all company activities. Thus, the entrepreneur has a unidirectional relationship with management $(\mathrm{E})$, innovative actions $(\mathrm{F})$, and customers $(G)$.

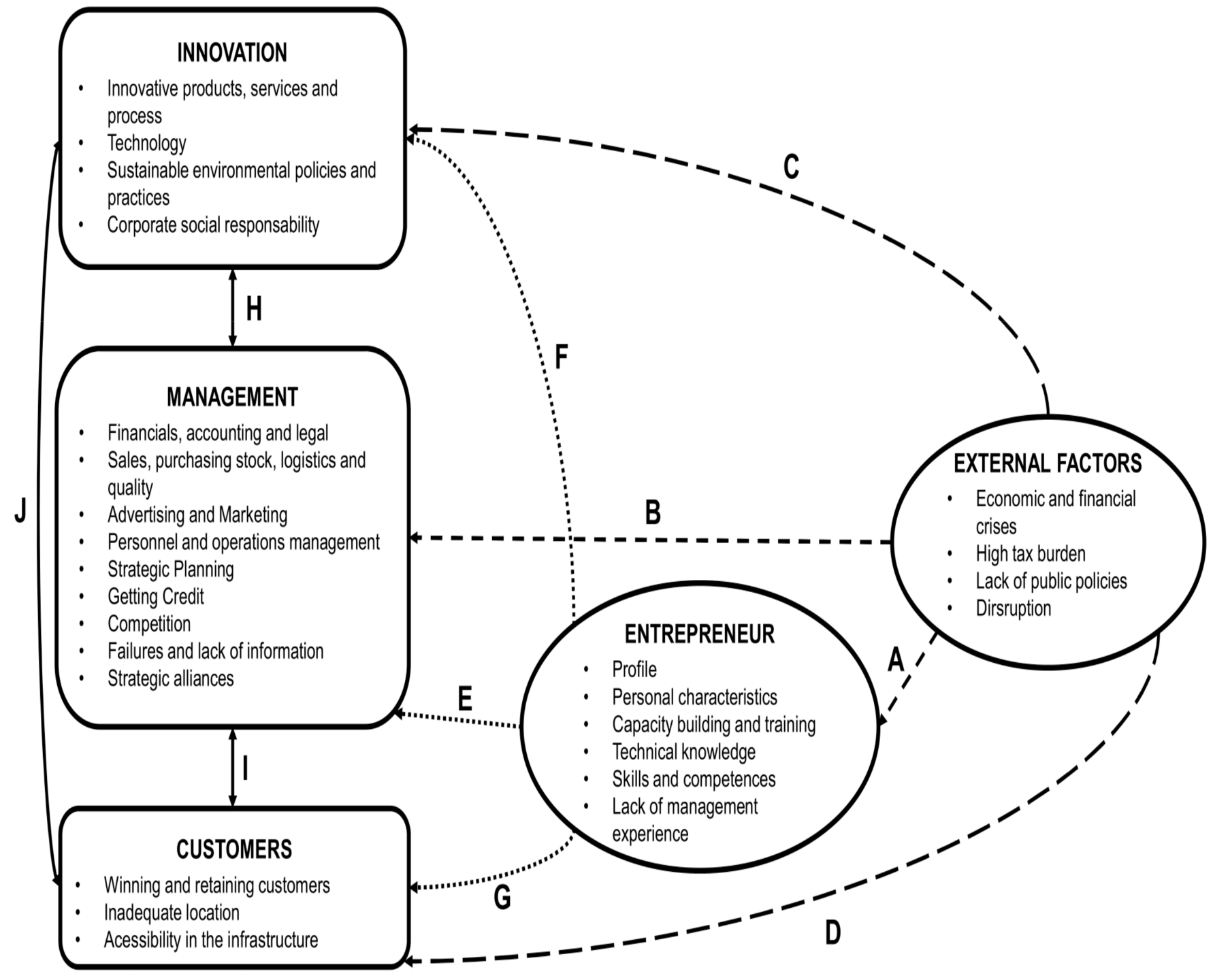

Figure 5. Conceptual model of mortality risk in MSE.

Considering the perspectives of management, innovation, and customers, a multidirectional relationship was found. This means that these dimensions are connected and the impact on the company's management will affect innovation processes and the relationship with the customer and vice versa. In-depth discussions of the model are presented in the next section. 


\subsection{Multidimensional Relationship}

The conceptual model presented the interrelationships between the five main dimensions. A change in one dimension may impact other dimensions. Presenting these relationships, it is expected that researchers, students, industry professionals, and entrepreneurs can have a broader understanding of the risk of mortality in MSEs. First, there is the dimension of external forces that affect the entrepreneur in his actions and decisions in such companies (A). Business management is influenced by external factors in its daily operations and organizational processes (B). In this case, economic and financial crises, changes in public policies related to the sector, and the disruptive effects of wars, pandemics, and epidemics impact the entrepreneur and decision-making in the company's operations.

In the relationship of external factors with innovation, it was found that to invest in innovative products and/or services, the company must have available resources [66], and for that, government support is essential (C). For this, public policies to support the sector are necessary, so MSEs can continue to compete in the market. There are other types of investments that need resources, such as technology, acquisition of machinery and equipment, and modernization of the company $[23,46,47,60,78]$. The government supports small enterprises through lines of credit from financial institutions, offering reduced interest rates and a grace period for payment. Therefore, micro and small entrepreneurs need to know the sources of fundraising and existing economic subsidy projects. Public policies to support the sector and emergency measures in times of crisis help in the creation and development of projects.

The relationship of external factors with customers occurs when their purchasing power is affected. For example, unemployment and inflation cause a reduction in demand for products and services (D). With the decreased demand, companies reduce sales and profit, and consequently, are affected in their performance.

Secondly comes the entrepreneurial dimension, which is related to the dimensions of management, innovation, and customers. Entrepreneurs are responsible for the company and all their decisions are based on their entrepreneurial characteristics [6], skills, and abilities (E). The MSE depends on the entrepreneur's performance, which in turn influences execution, survival, or mortality [16]. Among the necessary skills, the following stand out: persistence, proactivity [24], leadership, motivation, communication, critical capacity, perception $[25,62]$, resilience, and flexibility. Developing skills and competencies means discovering qualities and potential that will help achieve the planned goals. The entrepreneur needs to be aware of changes in the market to identify business opportunities [51]. The development of strategic planning, process mapping, cost and expense control, resources, and working capital optimization can combine to reduce failures and improve management $[3,16,25,62,65,108,120,121]$. A lack of entrepreneurial characteristics, management experience, and technical knowledge in the entrepreneur [124] end up negatively affecting the management of MSEs.

The entrepreneur's actions regarding innovation are essential for the company to be able to position itself in the market (F). Investing in innovative products, services and technology creates a competitive advantage $[23,46,47,54,60,78]$. Many entrepreneurs do not innovate because they do not know the existing tools and they fear change. Therefore, the entrepreneur needs to be up to date in his field of activity, participating in qualifications and training that will result in technical knowledge. The existing dynamic relationship of the entrepreneur with customers, on the other hand, concerns the development of strategies to attract and retain consumers $(G)[15,16,49,61]$. The entrepreneur must know his consumer, seeking to meet their needs and satisfy their desires. The tools used to conquer this target audience include training with sales personnel so that salespeople get to know the company's product, excellence in customer service, dissemination of products and services over the internet and through applications, social networks and advertising campaigns, adequate planning to achieve goals and objectives, a good relationship with the supplier so that there is no shortage of products in stock, the launch of quality products, and attractive prices and payment terms. 
In third place are the interrelated dimensions, which are: innovation, management, and customers. Innovation is interrelated with management, as innovation in products, services, and processes is the result of a set of strategic actions by managers to improve competitiveness $(\mathrm{H})$. Innovation interrelates with customers, as it represents a differential when choosing a product $(\mathrm{J})$. Customers are more demanding in the quality of products and/or services, in quick solutions, and the use of digital tools, such as websites, applications, internet sales, and social networks. In the interrelationship of management with customers, the important thing is to seek information about customer needs in order to retain them, as well as to win new customers (I) [61]. It is essential to invest in points of sale that are used by consumers and that are bringing revenue to the company. The satisfied customer discloses this information and this results in new consumers.

\subsection{Relationship between Subdimensions and Risk of Mortality in MSEs}

After understanding the relationships between the mortality risk dimensions (Figure 5), this section presents the relationships between the factors (subdimensions) and business mortality risk. The model was developed by the authors based on the articles mentioned in this review. Thus, it was possible to verify how the occurrence of factors linked to the entrepreneur, management, innovation, customers, and external factors dimensions lead MSEs to the risk of mortality (Figure 6). Arrows represent unidirectional (one direction) or multidirectional (multiple directions) relationships, showing a cause-and-effect relationship.

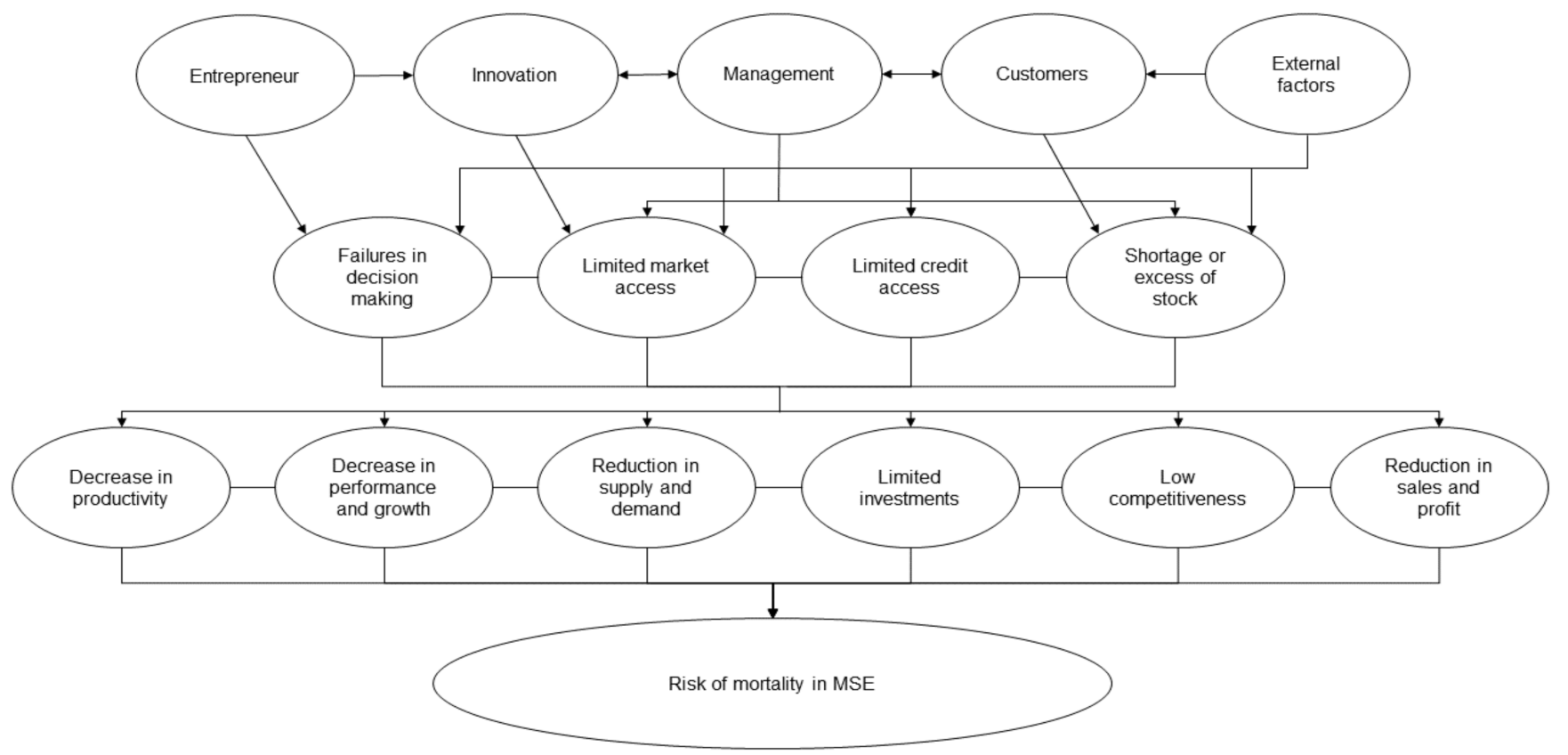

Figure 6. Relationship between factors and risk of mortality in MSE.

The factors linked to the entrepreneur influence decision making, which must be based on technical knowledge and experience-not intuition. The entrepreneur's level of education, business experience, skills, and competencies have a positive relationship with the profitability of the business [5,124]. On the other hand, the lack of these elements negatively impacts the company's profitability and productivity. The personal characteristics, skills, competencies, and profile of the entrepreneur can impact the company's daily operations. If an error is made in the decision-making process, personal and organizational damage may occur. This leads the company to face problems and reduction in demand, increasing the MSE's risk of mortality.

In management, risk factors generate limitations in market access, access to credit, and shortages or excesses of stock. Management problems cause the company difficulties in positioning itself in the market, in obtaining loans from financial institutions, and in the 
lack or excess of products in stock. When MSEs face obstacles that limit their investments and that limit their access to capital, their performance is poor [84].

In innovation, the emergence of risk factors in this dimension leads MSEs to diminished market access. The entrepreneur who is not prepared to adapt to changes in a competitive market will not survive. A lack of investment in the development of innovative products, services and processes, and in technology will limit the SME. In a globalized world, technology and product innovation are essential for a company to minimize its risk of mortality. The use of technological tools provides a competitive advantage in the market when compared to organizations that do not have them [118].

Risk factors associated with the customer cause the company to have limited access to the market; that is, if the focus is not on satisfying needs, desires and problem solving, the company will have difficulties retaining and winning new customers. Problems with customers have also been found to cause shortages or excess inventory. The stock must keep up with the demands of the customers. If there is no turnover, it means that sales are reduced and that the operating profit will be lower. Another problem is a lack of products in stock. When one has fewer products in stock, one takes the risk of not having what the customer needs. Therefore, one loses customers and stops winning new consumers, increasing the chances of mortality. With market competitiveness, customers are demanding and have increased awareness, thus seeking diversity, speed, quality, fair prices, and innovative products and services [42].

In the risks related to external factors, we underscore that MSEs that do not receive support and incentives from the government for the development and creation of new ventures will find limitations in market access, access to credit, and shortage or excess of products. Government assistance appears in the elaboration of public policies that reduce the tax burden and interest rates for access to credit with financial institutions, for example. High taxes limit the performance and growth of MSEs, as they reduce their sources of financing, discouraging business expansion [84]. The tax system needs to be restructured to encourage growth in MSEs [84]. The external environment also interferes with the entrepreneur's decisions, because, depending on the economic-financial situation and the disruptive effects, the entrepreneur may need to prepare for a crisis.

All risk factors, when they occur, result in a reduction in productivity [5], performance, growth [84], demand, sales, profit, investments [118], and competitiveness [118], leading MSEs to mortality risk.

\subsection{Model Validation}

The conceptual model can be validated by quantitative studies that were used to test and validate hypotheses about the relationships between the dimensions and their respective subdimensions (Figure 5). Marques et al. [118] carried out an empirical research in MSEs located in the northeast region of Mexico to verify the critical factors that influence the implementation of technological tools, with a focus on IT. Thus, with the application of the factor analysis technique, it was verified that the adoption of technological tools helps in the management of MSEs, allowing an increase in productivity and a strategy for facing risks. The quantitative study by Tunes and Monteiro [74] also used the technique of exploratory factor analysis and correlation to understand whether technical knowledge in management, from the perspective of the entrepreneur, generates an impact on business performance. The management knowledge bases considered were finance and accounting, innovation in processes and design, marketing and sales, human resources, legislation and taxes, and logistics. The results showed that management knowledge constitutes a competitive advantage for MSEs and a positive impact on the organization's performance was confirmed.

Severo et al. [51,102] surveyed 226 companies in the industrial, trade, and services sectors to analyze the relationships between project management, product and process innovation, and sustainability in companies in southern Brazil. The hypotheses were tested through structural equation modeling, confirmatory factor analysis, and hypothesis 
testing. The study showed that MSEs have proactive behaviors, as they present innovative actions for permanence and competitiveness in the market. Cassells and Lewis [93], in their quantitative research, explored the attitudes and experiences that prove the relationship of sustainability with associated training. The study was conducted with owner-managers of MSEs in New Zealand's manufacturing sector. For this, the techniques of Binary Logistic Regression and non-parametric tests were used. The results showed that there is an influence on the environmental awareness of companies involved in environmental training.

\section{Future Research Agenda}

The research gaps mentioned in the analyzed studies were organized into themes and subthemes, with research questions that need further investigation in the area. Thus, the agenda is dynamic and offers suggestions for future work (Table 12).

Table 12. Agenda and suggestions for future research on the risk of mortality in MSE.

\begin{tabular}{|c|c|c|}
\hline Topic & Subtopic & Relevant Future Research Questions \\
\hline Entrepreneur Profile & Entrepreneur profile and continuity of MSEs & $\begin{array}{l}\text { How the profile of the entrepreneur can affect the } \\
\text { continuity of MSEs [6]? }\end{array}$ \\
\hline \multirow{3}{*}{ Sustainability } & Challenges of women microentrepreneurs & $\begin{array}{c}\text { What are the critical factors that impede and } \\
\text { consolidate the sustainability of MSEs led by women } \\
\text { entrepreneurs [63]? }\end{array}$ \\
\hline & Sustainable business models & $\begin{array}{l}\text { What are the appropriate and viable methods for } \\
\text { designing sustainable business models in MSE [50]? }\end{array}$ \\
\hline & MSE performance & $\begin{array}{c}\text { How is the performance of MSEs located in developed } \\
\text { countries and MSEs located in developing countries } \\
\text { presented, and what are the existing gaps for business } \\
\text { survival [24]? }\end{array}$ \\
\hline \multirow{4}{*}{ Innovation } & Implementation of new technologies & $\begin{array}{l}\text { How do the sectors in which MSEs operate in the } \\
\text { implementation of new technologies [50]? }\end{array}$ \\
\hline & Innovation and geographic location & $\begin{array}{c}\text { What are the factors that determine innovation in MSE } \\
\text { based on geographic location [104]? }\end{array}$ \\
\hline & Barriers to innovation in MSEs & $\begin{array}{l}\text { What are the crucial impediments to innovation in } \\
\text { MSEs belonging to developing countries, concerning } \\
\text { the bureaucratic barriers of Doruk and Söylemezoglu } \\
\text { (2014) [105]? }\end{array}$ \\
\hline & Benefits of information technology for MSEs & $\begin{array}{l}\text { How do MSEs behave before and after IT investments, } \\
\text { from the point of view of evolution in organizational } \\
\text { performance [111]? }\end{array}$ \\
\hline \multirow{3}{*}{$\begin{array}{l}\text { Disruptive forces } \\
\text { COVID Pandemic }\end{array}$} & Impact of the pandemic on informal MSEs & $\begin{array}{l}\text { What is the impact of the pandemic on informal MSEs } \\
\text { and government plans for support during the crisis } \\
\text { period [26]? }\end{array}$ \\
\hline & CRS in the post-coronavirus period & $\begin{array}{l}\text { What are the opportunities and challenges for } \\
\text { corporate social responsibility (CSR) in the long term } \\
\text { post-coronavirus [52]? }\end{array}$ \\
\hline & Employees' perspectives in facing the crisis & $\begin{array}{l}\text { What are the perspectives of employees at MSEs, } \\
\text { concerning operations and strategies to face the } \\
\text { Coronavirus crisis [69]? }\end{array}$ \\
\hline
\end{tabular}

The first theme was related to the entrepreneur, in which it was suggested to analyze how the entrepreneur's profile can affect the continuity of the company. The profile consists of the entrepreneur's characteristics, such as gender, age, education, marital status, among others. The second theme was linked to sustainability, which recommended a study with women entrepreneurs to explore the critical factors that impede the sustainability of MSEs. Entrepreneurship activities have been recognized as a channel to unite gender, 
showing a gap for inequality [63]. Another study mentioned focused on the redefinition of sustainable business models. With the impact of the pandemic, it is essential to develop skills, improve professionals, seek business opportunities, and implement technologies within business models [50]. The other proposal was to verify the performance of MSEs inserted in developed and developing countries. The idea was to compare the MSEs in the two scenarios and find gaps that could be used to avoid business mortality.

The third theme was about innovation. Walter et al. [104] visualized the need to identify the factors that determine innovation, taking into account the geographic location of MSEs. The purpose was to verify whether there are differences in factors when considering local innovation systems. Another study investigated the bureaucratic side of innovative policies (costs and startup procedures) as the main impediments to innovation [105]. Bureaucratic barriers were proposed of restrictions on innovation in developing countries. Another recommendation was to evaluate the performance of MSEs before and after IT investments, verifying the benefits of IT in avoiding the risk of business mortality.

The fourth theme was linked to the pandemic to gain a better understanding of the effects of this crisis on formal and informal companies. Informal workers refer, for example, to street vendors and traders in open spaces, which were some of the most affected occupations in the informal sector [26]. The concern of investigating not only the entrepreneur's vision for facing the pandemic, but also employees' perspectives, was verified. Employees have a lot to contribute in terms of operations and strategies, as they are on the front lines, in contact with the customers. CSR represents the cooperation of companies for sustainable development, so it is important to identify the challenges and opportunities in the long term after the pandemic.

The most urgent research questions were related to this crisis. The theme is current and contributes to the literature on coping strategies, where business survival is fundamental. The topic involving informal MSEs was proposed by Akuoko et al. [26] in the argument that 'informality is an integral part of urban life and, therefore, the informal economic sector needs to be integrated and managed to reduce the socioeconomic impact of the pandemic'. For the authors, the pandemic showed the abandonment of the informal economy by the public sector. If these workers were in formal jobs, they would have social security and would resist social distancing and lockdowns. Another highlighted future study was proposed by Smart et al. [69] to include in the discussion of strategies to fight the pandemic, not only senior management but also employees and intermediate management, thus offering a comprehensive view of operations.

\section{Conclusions}

This study aimed to analyze the factors that determine the risk of mortality in MSEs, and to verify the state of the art on the topic of business mortality. From a systematic literature review, a list of determinants of mortality risk was made, and a conceptual model was drawn up showing the relationships between the dimensions of risk and its critical determinants. One hundred and six published articles were analyzed, and the results showed 36 risk factors for mortality. The identified risk dimensions were: entrepreneur, management, innovation, customers, and external factors. In the entrepreneur dimension, the most frequently cited factor was 'management skills and abilities'; in management, 'problems in economic and financial management'; in innovation, 'the lack of innovation in the development of products, services, and processes'; in customers, 'inadequate location' and in external factors, the 'the disruptive forces'.

The dimensions that stood out the most for the number of risk determinants were: management, entrepreneur, and innovation. In 'entrepreneur', we highlight the importance of improving skills and competencies that will reflect on the organization's productivity. In management, the entrepreneur must know all the necessary and available tools for good business performance and minimization of failures while improving management. Through innovation, products and services are created to serve consumers, and organizational processes are streamlined to improve business productivity. 
The disruptive force of the pandemic was the most frequently mentioned external factor and represents an unexpected situation with an unknown duration for businesses. However, these uncertainties and threats must be considered by the managers as opportunities to take advantage of new business opportunities, and, for that, strategic positioning is necessary, both for micro and small businesses as well as for medium and large enterprises.

This research helps entrepreneurs to identify their weaknesses and look for mechanisms to help in the elaboration of strategic actions and in directing investments for the company. Furthermore, our findings can guide government officials in the elaboration of public policies that support MSEs in innovative projects, in facilitating access to credit for working capital and investments, in reducing informality, and in providing support in creating new ventures. At the academic level, this investigation helps in the formation of entrepreneurs, identifying their difficulties, thus offering assistance for personal and business training. It is also academically relevant in the development of scientific research in specific segments using methodologies that bring answers to the sector.

Finally, it stands out that successful entrepreneurs are those who have their skills developed and who make their decisions based on knowledge and not intuition, and who are always attentive to the operations of the internal environment and the trends and changes in the external environment, seeking to detect and transform problems into possible business opportunities.

\section{Management Implications}

This study identified the determinants of mortality risk in MSEs, as well as alternatives for minimizing risk in these businesses.

For entrepreneurs, we recommend investing in education through qualifications and training. Learning leads to decision-making based on technical knowledge. Moreover, it helps the entrepreneur to learn about new technological, management, and innovation tools that can be applied in businesses. The acquired knowledge impacts entrepreneurial capacity - knowing how to do it—which, in turn, impacts entrepreneurial competencies, know-how, and knowing how to act [42]. It is added that technical knowledge helps in organizational activities, making them more effective for the success of MSEs. Topics such as financial education and digital technologies are suggested as training for entrepreneurs.

In business management, the importance of cooperation networks (networking) is highlighted, in order to establish partnerships (formal and informal) in all aspects between stakeholders. Networks become an alternative for the survival of MSEs and can help them to become competitive and sustainable [5]. Smart et al. [69] suggest the development of a cooperation plan to be used in the face of success and crisis.

In innovation, investment in technological tools is suggested, which provides a competitive advantage in any sector and business activity. The use of digital technologies positively affects the performance of the company, also impacting the satisfaction of employees and customers and facilitating tasks. The costs of acquisition and, frequently, of adaptation in the company's structure can be high, but the entrepreneur must think about the cost-benefit and the return that he will have in the medium and long term. An absence of technology limits the development of MSEs, besides reducing their competitiveness in the market [118].

As for customers, it appears that they are increasingly demanding and aware due to competition in the market [42]. Therefore, it is proposed that MSEs offer customers innovative and high-quality products and/or services at a fair price. For this, the company must know its target audience to identify their consumption needs and desires. This information can be collected through market research involving consumers, suppliers, employees, and even competitors. It is important for companies to adapt to their customers, and for that it is necessary to know their limitations and habits. Complaints, customer losses, and comments on social media should also be considered. 
Regarding external factors, particularly in the case of the pandemic, companies must develop a strategic plan to survive unexpected crises, including safety standards in operations, employee health, and alternatives for dealing with similar crises. Therefore, MSEs must learn from their previous experiences, analyze strengths, weaknesses, and threats in their market segment, and assess their resilience in the face of crisis [69] It is worth noting the importance of identifying companies that grew during the crisis, in order to better know the management practices that brought positive results, so that they can be adapted to MSEs.

Author Contributions: Conceptualization: F.T.G. and D.A.d.J.P.; methodology: F.T.G., E.A.R.d.C. and D.A.d.J.P; software: F.T.G.; formal analysis: F.T.G. and A.M.C.; investigation: F.T.G., C.S.t.C. and E.A.R.d.C.; data curation: F.T.G.; writing—original draft preparation: F.T.G., C.S.t.C., E.A.R.d.C. and A.M.C.; writing-review and editing: F.T.G., C.S.t.C., E.A.R.d.C., A.M.C. and D.A.d.J.P; visualization: F.T.G., D.A.d.J.P. and C.S.t.C.; supervision: C.S.t.C., A.M.C. and D.A.d.J.P.; project administration: F.T.G. All authors have read and agreed to the published version of the manuscript.

Funding: This research was funded by the Brazilian Ministry of Education-Conselho Nacional de Desenvolvimento Científico e Tecnológico (Cnpq) process no. 161940/2020-0.

Institutional Review Board Statement: Not applicable.

Informed Consent Statement: Not applicable.

Conflicts of Interest: The authors declare no conflict of interest.

\section{Appendix A}

Table A1. Works Selected for Systematic Review.

\begin{tabular}{|c|c|c|}
\hline ID & Journal & Source \\
\hline 1 & Africa Journal of Management & Acquaah and Agyapong (2015) \\
\hline 2 & African Development Review & Ishengoma and Kappel (2011) \\
\hline 3 & African Journal of Business Management & Fatoki and Garwe (2010) \\
\hline 4 & African Journal of Business Management & Simeyo et al. (2011) \\
\hline 5 & African Journal of Information Systems & Perekwa et al. (2016) \\
\hline 6 & Applied Economics & Laguir and Den Besten (2016) \\
\hline 7 & Asian Economic Policy Review & Kurosaki (2019) \\
\hline 8 & Brazilian Journal of Operations and Production Management & Anholon et al. (2015) \\
\hline 9 & Brazilian Journal of Operations and Production Management & Braga (2018) \\
\hline 10 & Brazilian Journal of Public Administration & Nogueira et al. (2020) \\
\hline 11 & Cogent Business and Management & Agyapong et al. (2017) \\
\hline 12 & Cogent Business and Management & Atnafu and Balda (2018) \\
\hline 13 & Cogent Business and Management & Pozo et al. (2019) \\
\hline 14 & Cuadernos de Administración & Marques et al. (2019) \\
\hline 15 & Development Southern Africa & Chirwa (2008) \\
\hline 16 & Economia & Conceição et al. (2018) \\
\hline 17 & Economic Journal of Emerging Markets & Sulistya and Darwanto (2016) \\
\hline 18 & Economics Bulletin & Laguir et al. (2017) \\
\hline 19 & Engineering, Construction and Architectural Management & Mahamid (2012) \\
\hline 20 & European Business Review & Alonso and Kok (2020) \\
\hline 21 & Evaluation and Program Planning & Cardoso et al. (2020) \\
\hline 22 & FIIB Business Review & Alon et al. (2020) \\
\hline 23 & Gestão e Desenvolvimento & De Paulla and Hamza (2015) \\
\hline
\end{tabular}


Table A1. Cont.

\begin{tabular}{|c|c|c|}
\hline ID & Journal & Source \\
\hline 24 & Gestão e Produção & Ferreira et al. (2012). \\
\hline 25 & Global Business Review & Kazungu (2020) \\
\hline 26 & Heliyon & Lukiyanto and Wijayaningtyas (2020) \\
\hline 27 & Holos & Walter et al. (2019) \\
\hline 28 & IEEE Latin America Transactions & Willerding et al. (2012) \\
\hline 29 & Independent Journal of Management and Production-IJM\&P & Galvão et al. (2020) \\
\hline 30 & Information Development & Malaquias and Hwang (2016) \\
\hline 31 & Information Technology for Development & Moyi (2003) \\
\hline 32 & Information Technology for Development & Owoseni and Twinomurinzi (2020) \\
\hline 35 & Innovation and Development & Quiroz-Rojas and Teruel (2020) \\
\hline 33 & Innovation and Management Review & Berne et al. (2019) \\
\hline 34 & Innovation and Management Review & Vasconcelo and Oliveira (2018) \\
\hline 36 & International Business Review & Pezderka and Sinkovic (2011) \\
\hline 37 & International Business Review & Amankwah-Amoah et al.(2021) \\
\hline 38 & International Journal of Business and Society & Ya'kob and Jusoh (2016) \\
\hline 39 & International Journal of Engineering and Technology & Ratnaningtyas et al. (2018) \\
\hline 40 & International Journal of Entrepreneurial Behavior and Research & Atiase et al. (2019) \\
\hline 41 & International Journal of Hospitality Management & Smart et al. (2021) \\
\hline 42 & International Journal of Innovation & Alvarenga (2016) \\
\hline 43 & International Journal of Innovative Technology and Exploring Engineering & Ramgir (2019) \\
\hline 44 & International Journal of Production Research & Gunasekaran et al. (2011) \\
\hline 45 & International Journal of Recent Technology and Engineering & Alshami et al. (2019) \\
\hline 46 & International Journal of Scientific and Technology Research & Hadiyati and Lukiyanto (2019) \\
\hline 47 & International Journal of Technology and Human Interaction & Chege et al. (2020) \\
\hline 48 & International Journal of Wine Business Research & Alonso and Bressan (2016) \\
\hline 49 & International Research Journal of Finance and Economics & Abor and Quartey (2010) \\
\hline 50 & International Review of Applied Economics & Aga and Reilly (2011) \\
\hline 51 & Journal of African Business & Agyapong et al. (2019) \\
\hline 52 & Journal of Business Management Studies & Gupta and Tripathi (2020) \\
\hline 53 & Journal of Business Research & He and Harris (2020) \\
\hline 54 & Journal of Business Research & Xu et al. (2020) \\
\hline 55 & Journal of Business Venturing & Cruz et al. (2012) \\
\hline 56 & Journal of Cleaner Production & Rahbauer et al. (2016) \\
\hline 57 & Journal of Education and Work & McGrath (2005) \\
\hline 58 & Journal of International Development & Donner and Escobari (2010) \\
\hline 59 & Journal of Macromarketing & Blankson et al. (2018) \\
\hline 60 & Journal of Management and Technology. & Quelhas (2019) \\
\hline 61 & Journal of Small Business and Enterprise Development & Cassells and Lewis (2017) \\
\hline 62 & Journal of Small Business and Enterprise Development & Fielden et al. (2000) \\
\hline 63 & Journal of Small Business and Enterprise Development & Shibia and Barako (2017) \\
\hline 64 & Journal of Small Business and Entrepreneurship & Agyapong et al. (2020) \\
\hline 65 & Journal of Small Business and Entrepreneurship & Alonso and Bressan (2017) \\
\hline 66 & Journal of Small Business and Entrepreneurship & Chikweche and Bressan (2017) \\
\hline
\end{tabular}


Table A1. Cont.

\begin{tabular}{|c|c|c|}
\hline ID & Journal & Source \\
\hline 67 & Journal of Small Business Management & Liberman-Yaconi et al. (2010) \\
\hline 68 & Management and Marketing & Gavurova et al. (2021) \\
\hline 69 & Management and Marketing & Păunescu and Mátyus (2020) \\
\hline 70 & Organizations and Markets in Emerging Economies & Rascón and Velazquez (2019) \\
\hline 71 & Pacific Business Review International & Khan and Shah (2016) \\
\hline 72 & Pertanika Journal of Social Science and Humanities & Manor and Desiana (2018) \\
\hline 73 & Prague Economic Papers & Skýpalová et al. (2016) \\
\hline 74 & Procedia—Social and Behavioral Sciences & Jamak et al. (2014) \\
\hline 75 & Procedia—Social and Behavioral Sciences & Mahzan and Yan (2014) \\
\hline 76 & Procedia—Social and Behavioral Sciences & Rahayu and Day (2015) \\
\hline 77 & Procedia—Social and Behavioral Sciences & Zaridis and Mousiolis (2014) \\
\hline 78 & Procedia Economics and Finance & Bhattacharya and Londheb (2014) \\
\hline 79 & Procedia Economics and Finance & Gicã and Balinta (2012) \\
\hline 80 & Procedia Economics and Finance & Irjayanti and Azis (2012) \\
\hline 81 & Procedia Economics and Finance & Rupeika-Apoga (2014) \\
\hline 82 & Procedia Economics and Finance & Stacho et al. (2015) \\
\hline 83 & Procedia Economics and Finance & Vera (2012) \\
\hline 84 & Procedia Economics and Finance & Zager et al. (2016) \\
\hline 85 & Proceedings of the National Academy of Sciences of the United States of America & Bartik et al. (2020) \\
\hline 86 & Production Planning and Control & Severo et al. (2019) \\
\hline 87 & Quality & Walter et al. (2019) \\
\hline 88 & Revista Brasileira de Marketing & Tunes and Monteiro (2017) \\
\hline 89 & Revista Capital Científico & Machado and Espinha (2005) \\
\hline 90 & Revista de Gestão & Leoneti et al. (2016) \\
\hline 91 & Revista de Gestão e Tecnologia & Bohn et al. (2018) \\
\hline 92 & Revista de Sistemas de Información Y Documentación & Woida (2019) \\
\hline 93 & Revista Eletrônica de Estratégia e Negócios & Santini et al. (2015) \\
\hline 94 & Revista Eletrônica de Estratégia e Negócios & Tavares and Mario (2018) \\
\hline 95 & Small Enterprise Research & Corner et al. (2002) \\
\hline 96 & Small Enterprise Research & Nosratabadi (2020) \\
\hline 97 & Social Sciences and Humanities Open & Akuoko et al. (2021) \\
\hline 98 & Sustainability & Baig et al. (2020) \\
\hline 99 & Sustainability & Gregurec et al. (2021) \\
\hline 100 & Technical Gazette & Vorkapić et al. (2017) \\
\hline 101 & Tourism Planning and Development & Bressan and Pedrini (2019) \\
\hline 102 & Transformations in Business and Economics & Duda et al. (2017) \\
\hline 103 & World Academy of Science, Engineering and Technology & Arslan and Kivrak (2008) \\
\hline 104 & World Development & Mano et al. (2012) \\
\hline 105 & World Development & Shiferaw (2009) \\
\hline 106 & World Development & Nordhagen et al. (2021) \\
\hline
\end{tabular}




\section{Appendix B}

Table A2. Frequency of Mortality Risk Dimensions and Subdimensions in the Analyzed Articles.

\begin{tabular}{|c|c|c|c|c|}
\hline Dimensions & Subdimensions & Absolute Frequency & $\begin{array}{l}\text { Relative Frequency in the } \\
\text { Dimension (\%) }\end{array}$ & $\begin{array}{c}\text { Relative Frequency in Total } \\
(\%)\end{array}$ \\
\hline \multirow{7}{*}{ Entrepreneur } & Management skills and competences & 12 & 25 & 5.4 \\
\hline & Profile & 11 & 22.9 & 5.0 \\
\hline & Lack of capacity building and training & 07 & 14.6 & 3.1 \\
\hline & Lack of experience in business management & 06 & 12.5 & 2.7 \\
\hline & Personal characteristics & 06 & 12.5 & 2.7 \\
\hline & Lack of technical knowledge & 06 & 12.5 & 2.7 \\
\hline & Subtotal & 48 & 100 & 21.9 \\
\hline \multirow{19}{*}{ Management } & $\begin{array}{l}\text { Problems in economic and } \\
\text { financial management }\end{array}$ & 19 & 19.5 & 8.6 \\
\hline & Difficulty in obtaining credit & 18 & 18.5 & 8.2 \\
\hline & Lack of strategic planning & 07 & 7.2 & 3.1 \\
\hline & $\begin{array}{l}\text { Failures, underutilization, and lack } \\
\text { of information }\end{array}$ & 07 & 7.2 & 3.1 \\
\hline & $\begin{array}{l}\text { Lack of strategic alliances and } \\
\text { cooperation networks }\end{array}$ & 06 & 6.1 & 2.7 \\
\hline & Problems in accounting management & 05 & 5.1 & 2.2 \\
\hline & Quality management problems & 05 & 5.1 & 2.2 \\
\hline & Problems in Strategic Management & 05 & 5.1 & 2.2 \\
\hline & Sales management issues & 05 & 5.1 & 2.2 \\
\hline & Problems in marketing management & 05 & 5.1 & 2.2 \\
\hline & Problems in personnel management & 04 & 4.1 & 1.8 \\
\hline & Operations management problems & 02 & 2 & 0.9 \\
\hline & Inventory management problems & 02 & 2 & 0.9 \\
\hline & High competition & 02 & 2 & 0.9 \\
\hline & Lack of advertising & 02 & 2 & 0.9 \\
\hline & Lack of legal guidance & 01 & 1 & 0.4 \\
\hline & Problems in logistics management & 01 & 1 & 0.4 \\
\hline & Problems in purchasing management & 01 & 1 & 0.4 \\
\hline & Subtotal & 97 & 100 & 44.2 \\
\hline \multirow{5}{*}{ Innovation } & $\begin{array}{l}\text { Lack of innovation in the development of } \\
\text { products, services, and processes }\end{array}$ & 18 & 51 & 8.2 \\
\hline & Lack of Technologies & 13 & 29.7 & 5.9 \\
\hline & $\begin{array}{l}\text { Lack of sustainable environmental policies } \\
\text { and practices }\end{array}$ & 04 & 10.6 & 1.8 \\
\hline & Absence of corporate social responsibility & 01 & 8.5 & 0.4 \\
\hline & Subtotal & 36 & 100 & 18.3 \\
\hline \multirow{5}{*}{ Customers } & Inadequate location & 04 & 33.3 & 1.8 \\
\hline & Difficulties in retaining customers & 03 & 25 & 1.3 \\
\hline & $\begin{array}{l}\text { Lack of adequacy and accessibility } \\
\text { in the infrastructure }\end{array}$ & 03 & 25 & 1.3 \\
\hline & Difficulties in winning customers & 02 & 16.6 & 0.8 \\
\hline & Subtotal & 12 & 100 & 5.4 \\
\hline \multirow{6}{*}{$\begin{array}{l}\text { External } \\
\text { Factors }\end{array}$} & Disruptive forces & 11 & 42.3 & 5.0 \\
\hline & Economic and financial crises & 07 & 26.9 & 3.1 \\
\hline & High tax burden & 05 & 19.2 & 2.1 \\
\hline & Lack of public policies & 03 & 11.5 & 1.3 \\
\hline & Subtotal & 26 & 100 & 11.8 \\
\hline & Total & 219 & & 100 \\
\hline
\end{tabular}




\section{References}

1. Jabłońska, M.; Stawska, J. The key factors affecting entrepreneurship: A comparative analysis. Zb. Rad. Ekon. Fak. Rij. 2020, 38, 125-146. [CrossRef]

2. Rusu, V.D.; Roman, A. Entrepreneurial activity in the EU: An empirical evaluation of its determinants. Sustainability 2017, 9, 1679. [CrossRef]

3. Agyapong, F.O.; Agyapong, A.; Poku, K. Nexus between social capital and performance of micro and small firms in an emerging economy: The mediating role of innovation. Cogent Bus. Manag. 2017, 4, 1309784. [CrossRef]

4. Abor, J.; Quartey, P. Issues in SME development in Ghana and South Africa. Int. Res. J. Financ. Econ. 2010, 39, $215-228$.

5. Jamak, A.B.S.A.; Ali, R.M.M.; Ghazali, Z. A breakout strategy model of Malay (Malaysian indigenous) micro-entrepreneurs. Procedia-Soc. Behav. Sci. 2014, 109, 572-583. [CrossRef]

6. Rascón, O.C.A.; Velázquez, R.P. Factors that determine the closure or jeopardize the continuity of a micro and small enterprise. Organ. Mark. Emerg. Econ. 2019, 10, 78-91. [CrossRef]

7. Acquaah, M.; Agyapong, A. The relationship between competitive strategy and firm performance in micro and small businesses in Ghana: The moderating role of managerial and marketing capabilities. Afr. J. Manag. 2015, 1, 172-193. [CrossRef]

8. Zaridis, A.D.; Mousiolis, D.T. Entrepreneurship and SME's organizational structure. Elements of a successful business. ProcediaSoc. Behav. Sci. 2014, 148, 463-467. [CrossRef]

9. Conceição, O.C.; Saraiva, M.V.; Fochezatto, A.; França, M.T.A. Brazil's simplified tax regime and the longevity of Brazilian manufacturing companies: A survival analysis based on RAIS microdata. Economia 2018, 19, 164-186. [CrossRef]

10. Organization for Economic Co-Operation and Development (OECD). Small and Medium Enterprise Outlook 2002. Available online: https: / / www.oecd.org/sti/oecd-small-and-medium-enterprise-outlook-1999138x.htm (accessed on 15 November 2020).

11. Machado, H.P.V.; Espinha, P.G. Reflexões sobre as dimensões do fracasso e mortalidade de pequenas empresas. Rev. Cap. Cient.-Eletrônica 2005, 3, 51-64.

12. Gunasekaran, A.; Rai, B.K.; Griffin, M. Resilience and competitiveness of small and medium size enterprises: An empirical research. Int. J. Prod. Res. 2011, 49, 5489-5509. [CrossRef]

13. Liberman-Yaconi, L.; Hooper, T.; Hutchings, K. Toward a model of understanding strategic decision-making in micro-firms: Exploring the Australian information technology sector. J. Small Bus. Manag. 2010, 48, 70-95. [CrossRef]

14. Bartik, A.W.; Bertrand, M.; Cullen, Z.B.; Glaeser, E.L.; Luca, M.; Stanton, C.T. The impact of COVID-19 on small business outcomes and expectations. Proc. Natl. Acad. Scie. USA 2020, 117, 17656-17666. [CrossRef] [PubMed]

15. Santini, S.; Favarin, E.V.; Nogueira, M.A.; Oliveira, M.L.; Ruppenthal, J.A. Factors of mortality in micro and small enterprises: A study in the central region of Rio Grande do Sul. Rev. Eletrônica Estratég. Negócios 2015, 8, 145-170. [CrossRef]

16. Ferreira, L.F.F.; Oliva, F.L.; Santos, S.A.; Hildebrand, C.C.; Lima, G.A.C. A quantitative analysis of the premature mortality of small companies in the city of São Paulo. Gestão Produção 2012, 19, 811-823. [CrossRef]

17. Mahamid, I. Factors affecting contractor's business failure: Contractors' perspective. Eng. Constr. Archit. Manag. 2012, 9, $269-285$. [CrossRef]

18. Alonso, A.D.; Kok, S.K. Understanding critical success factors and perceived future among micro and small firms through entrepreneurial action theory. Eur. Bus. Rev. 2020, 33, 383-406. [CrossRef]

19. Kazungu, I. Network linkages and performance of exporting micro and small enterprises in Dar Es Salaam, Tanzania: Perspectives in the handicraft industry. Glob. Bus. Rev. 2020, 21, 0972150920934433. [CrossRef]

20. Baig, S.; Qasim, M.; Li, X.; Alam, K.M. Is the China-Pakistan economic corridor an opportunity or a threat for small and micro-entrepreneurs? Empirical evidence from Northern Pakistan. Sustainability 2020, 12, 1727. [CrossRef]

21. Atiase, V.Y.; Mahmood, S.; Wang, Y. Does institutional logic matter in microfinance delivery? An empirical study of microfinance clientes. Int. J. Entrep. Behav. Res. 2019, 26, 177-202. [CrossRef]

22. Owoseni, A.; Twinomurinzi, H. Evaluating mobile app usage by service sector micro and small enterprises in Nigeria: An abductive approach. Inf. Technol. Dev. 2020, 26, 762-772. [CrossRef]

23. Irjayanti, M.; Azis, A.M. Barrier factors and potential solutions for Indonesian SMEs. Procedia Econ. Financ. 2012, 4, 3-12. [CrossRef]

24. Gupta, S.; Tripathi, A. Performance measurement of micro \& small scale enterprises in developing countries-A study in Ethiopia. J. Bus. Manag. Stud. 2020, 16, 55-63. [CrossRef]

25. Alvarenga, R.A. Study of factors contributors to death of micro and small companies in the state of Maranhão. Int. J. Innov. 2016, 4, 106-118. [CrossRef]

26. Akuoko, P.B.; Aggrey, V.; Amoako-Arhen, A. Ghana's informal economic sector in the face of a pandemic. Soc. Sci. Humanit. 2020, 3, 100094. [CrossRef]

27. Arslan, G.; Kivrak, S. Critical factors to company success in the construction industry. World Acad. Sci. Eng. Technol. 2008, 45, 43-46. [CrossRef]

28. Roratto, R.; Dias, E.D.; Alves, E.B. Mortalidade em micro e pequenas empresas: Um estudo de caso na região central do Rio Grande do Sul. Revista Espacios 2017, 38, 1-11.

29. Confort, E.C.; Amaral, D.C.; Silva, S.L. Roadmap for systematic literature review: Application in product development and project management. In Proceedings of the VIII Brazilian Congress of Management and Product Development, Porto Alegre, Brazil, 25th March 2011. 
30. Dresch, A.; Lacerda, D.P.; Antunes, J. Design Science Research: Método de Pesquisa para Avanço da Ciência e Tecnologia, 1st ed.; Bookman: Porto Alegre, Brazil, 2015.

31. Tranfield, D.; Denyer, D.; Smart, P. Towards a Methodology for Developing Evidence-Informed Management Knowledge by Means of Systematic Review. Br. J. Manag. 2003, 14, 207-222. [CrossRef]

32. Moher, D.; Liberati, A.; Tetzlaff, J.; Altman, D.G. Preferred reporting items for systematic reviews and meta-analyses: The PRISMA statement. PLoS Med. 2009, 6, e1000097. [CrossRef]

33. Aaker, D.A.; Kumar, V.; Day, G.S. Pesquisa de Marketing, 2nd ed.; Atlas: São Paulo, Brazil, 2004.

34. Igarashi, M.; De Boer, L.; Fet, A.M. What is required for greener supplier selection? A literature review and conceptual model development. J. Purch. Supply Manag. 2013, 19, 247-263. [CrossRef]

35. Jabareen, Y. Building a Conceptual Framework: Philosophy, Definitions, and Procedure. Int. J. Qual. Methods 2009, 8, 49-62. [CrossRef]

36. Lindgreen, A.; Di Benedetto, C.A.; Brodie, R.J.; Jaakkola, E. How to develop great conceptual frameworks for business-to-business marketing. Ind. Mark. Manag. 2021, 94, A2-A10. [CrossRef]

37. Žukauskas, P.; Vveinhardt, J.; Andriukaitienė, R. Philosophy and Paradigm of Scientific Research. the chapter. In Management Culture and Corporate Social Responsibility; Žukauskas, P., Vveinhardt, J., Andriukaitienè, R., Eds.; BoD-Books on Demand: Norderstedt, Germany, 2018.

38. Sabour, M.R.; Derhamjani, G.; Akbari, M.; Hatami, A.M. Global trends and status in waste foundry sand management research during the years 1971-2020: A systematic analysis. Environ. Sci. Pollut. Res. 2021, 28, 37312-37321. [CrossRef]

39. Agyapong, A.; Zamore, S.; Mensah, H.K. Strategy and performance: Does environmental dynamism matter? J. Afr. Bus. 2019, 21, 315-337. [CrossRef]

40. Chikweche, T.; Bressan, A. A systematic review of future research challenges and prospects of organizational learning research in small medium size enterprises. J. Small Bus. Entrep. 2017, 30, 175-191. [CrossRef]

41. Wacker, J.G. A definition of theory: Research guidelines for different theory-building research methods in operations management. J. Oper. Manag. 1998, 20, 361-385. [CrossRef]

42. Willerding, I.A.V.; Prado, M.L.; Lapolli, E.M. A trilogy of entrepreneurship: Performance, capacity and competence as a factor of success for micro and small enterprises. IEEE Latin Am. Trans. 2012, 10, 2017-2024. [CrossRef]

43. Mahzan, N.; Yan, C.M. Harnessing the benefits of corporate governance and internal audit: Advice to SME. Procedia-Soc. Behav. Sci. 2014, 115, 156-165. [CrossRef]

44. Ramgir, M. An advanced framework to design a smart store system using IoT, AI, and data analytics that improves business processes for micro and small businesses. Int. J. Innov. Technol. Explor. Eng. 2019, 8, 150-153. [CrossRef]

45. Bhattacharya, S.; Londhe, B.R. Micro entrepreneurship: Sources of finance \& related constraints. Procedia Econ. Financ. 2014, 11, 775-783. [CrossRef]

46. Pezderka, N.; Sinkovics, R.R. A conceptualization of e-risk perceptions and implications for small firm active online internationalization. Int. Bus. Rev. 2011, 20, 409-422. [CrossRef]

47. Corner, P.; Bowden, S.; Clark, D. E-Business adoption and strategies in New Zealand SMEs: A descriptive study. Small Enterp. Res. 2002, 10, 43-61. [CrossRef]

48. Blankson, C.; Cowan, K.; Darley, W.K. Marketing practices of rural micro and small businesses in Ghana: The role of public policy. J. Macromark. 2018, 38, 29-56. [CrossRef]

49. Fielden, S.L.; Davidson, M.J.; Makin, P.J. Barriers encountered during micro and small business start-up in North-West England. J. Small Bus. Enterp. Dev. 2000, 7, 295-304. [CrossRef]

50. Gregurec, I.; Furjan, M.T.; Pupek, K.T. The impact of COVID-19 on sustainable business models in SMES. Sustainability 2021, 13, 1098. [CrossRef]

51. Alon, I.; Farrell, M.; Li, S. Regime type and COVID-19 response. FIIB Bus. Rev. 2020, 9, 152-160. [CrossRef]

52. He, H.; Harris, L.C. The impact of COVID-19 pandemic on corporate social responsibility and marketing philosophy. J. Bus. Res. 2020, 116, 176-182. [CrossRef]

53. Nogueira, M.O.; Silva, S.P.; Carvalho, S.S. From biological viruses to economic viruses: A vaccine for microenterprises in Brazil. Rev. Bras. Adm. Pública 2020, 54, 1010-1021. [CrossRef]

54. Donner, J.; Escobari, M.X. A review of evidence on mobile use by micro and small enterprises in developing countries. J. Int. Dev. 2010, 22, 641-658. [CrossRef]

55. Khan, F.A.; Shah, G.B. Efficiency measurement of EDP's: A comparative study of trained and untrained entrepreneurs of Anantnag District. Pac. Bus. Rev. Int. 2016, 8, 23-30.

56. Nosratabadi, J. The impact of small loan programmes on employment for micro and small enterprises: Evidence from a province in Iran. Small Enterp. Res. 2020, 27, 64-84. [CrossRef]

57. Duda, J.; Gasior, A.; Alebaite, I. Innovation of polish micro and small enterprises and trade credit. Transform. Bus. Econ. 2017, 16, 89-108.

58. Rahbauer, S.; Menapace, L.; Menrad, K.; Decker, T. Adoption of green electricity by German small and medium-sized enterprises (SMEs) - A qualitative analysis. J. Clean. Prod. 2016, 129, 102-112. [CrossRef]

59. Rupeika-Apoga, R. Access to finance: Baltic financial markets. Procedia Econ. Financ. 2014, 9, 181-192. [CrossRef] 
60. de Vera, I.J.M. An assessment of micro, small and medium enterprises that underwent UP ISSI's integrated plant surveys for the periode 2006 to 2011. Procedia Econ. Financ. 2012, 4, 350-364. [CrossRef]

61. Anholon, R.; Pinto, J.S.; Carpim, E.N.B.; Novaski, O.; Zoqui, E.J.; Ordonez, R.E.C. Micro and Small Enterprises management: Main administrative difficulties observed in construction sector enterprises. Braz. J. Oper. Prod. Manag. 2015, 12, 88-99. [CrossRef]

62. Ratnaningtyas, S.; Sutardi, A.; Makbul, Y. The influence of entrepreneurship capability to micro and small business growth in Indonesian fish processing industry. Int. J. Eng. Technol. 2018, 7, 100-105. [CrossRef]

63. Alshami, S.A.; Majid, I.; Rashid, N.; Adil, H. Women micro and small business sustainability in Malaysia through microcredit. Int J. Recent Technolo. Eng. 2019, 8, 70-74.

64. Lukiyanto, K.; Wijayaningtyas, M. Gotong Royong as social capital to overcome micro and small enterprises' capital difficulties. Heliyon 2020, 6, e04879. [CrossRef]

65. Galvão, E.M.; Valente, B.C.; Cotrim, S.L.; Galdamez, E.V.C.; Leal, G.C.L. A hybrid model for planning programming and control of production for micro and small enterprises. Indep. J. Manag. Prod. 2020, 11, 1163-1183. [CrossRef]

66. Pozo, H.; Akabane, G.K.; Tachizava, T. Innovation and technology processes in micro and small business. Cogent Bus. Manag. 2019, 6, 1588088. [CrossRef]

67. Bressan, A.; Pedrini, M. Exploring sustainable-oriented innovation within micro and small tourism firms. Tour. Plan. Dev. 2019, 17, 497-514. [CrossRef]

68. Amankwah-Amoah, J.; Khan, Z.; Osabutey, E.L.C. COVID-19 and business renewal: Lessons and insights from the global airline industry. Int. Bus. Rev. 2021, 30, 101802. [CrossRef]

69. Smart, K.; Ma, E.; Qu, H.; Ding, L. COVID-19 impacts, coping strategies, and management reflection: A lodging industry case. Int. J. Hosp. Manag. 2021, 94, 102859. [CrossRef]

70. Mano, Y.; Iddrisu, A.; Yoshino, Y.; Sonobe, T. How can micro and small enterprises in Sub-Saharan Africa become more productive? The impacts of experimental basic managerial training. World Dev. 2012, 40, 458-468. [CrossRef]

71. Chirwa, E. Effects of gender on the performance of micro and small enterprises in Malawi. Dev. South. Afr. 2008, 25, 347-362. [CrossRef]

72. Kurosaki, T. Informality, micro and small enterprises, and the 2016 demonetisation policy in India. Asian Econ. Policy Rev. 2019, 14, 97-118. [CrossRef]

73. Quiroz-Rojas, P.; Teruel, M. Does gender matter for innovative and non-innovative firms' growth? An empirical analysis of Chilean managers. Innov. Dev. 2020, 10, 49-67. [CrossRef]

74. Tunes, R.; Monteiro, P.R.R. Conhecimento em gestão, vantagem competitiva e performance empresarial: Proposição e teste de um modelo fundamentado na "Resource Advantage Theory" em MPEs. Rev. Bras. de Mark. 2017, 16, 298-316. [CrossRef]

75. Zager, K.; Tusek, B.; Jezovita, A. Analysis related to number of small and medium-sized companies respecting accounting legislation changes. Procedia Econ. Financ. 2016, 39, 433-440. [CrossRef]

76. Stacho, Z.; Stachová, K.; Hudáková, M. Approach of companies to customers as suitable source of incentive to innovate. Procedia Econ. Financ. 2015, 34, 11-18. [CrossRef]

77. Alonso, A.D.; Bressan, A. Collaboration among micro and small firms in a traditional industry. J. Small Bus. Entrep. 2017, 29, 57-75. [CrossRef]

78. Rahayu, R.; Day, J. Determinant factors of e-commerce adoption by SMEs in developing country: Evidence from Indonesia. Procedia-Soc. Behav. Sci. 2015, 195, 142-150. [CrossRef]

79. Shiferaw, A. Survival of private sector manufacturing establishments in Africa: The role of productivity and ownership. World Dev. 2009, 37, 572-584. [CrossRef]

80. Bohn, A.C.; Gambirage, C.; da Silva, J.C.; Hein, N.; Iargas, A.M. Factors that impact on the premature closure of small business enterprises: A study in the coastal area of Santa Catarina. Rev. Gestão Tecnol. 2018, 8, 43-56. [CrossRef]

81. Tavares, A.C.; Mario, P.C. Factors conditioning to the continuity of MPE of the city of Bom Despacho/MG. Rev. Eletrônica Estratég. Negócios 2018, 11, 54-86. [CrossRef]

82. Hadiyati, E.; Lukiyanto, K. The effect of entrepreneurial marketing dimensions on micro, small and medium enterprise performance in Indonesia. Int. J. Sci. Technol. Res. 2019, 8, 106-112.

83. Cruz, C.; Justo, R.; Castro, J.O. Does family employment enhance MSEs performance? Integrating socioemotional wealth and family embeddedness perspectives. J. Bus. Ventur. 2012, 27, 62-76. [CrossRef]

84. Ishengoma, E.K.; Kappel, R. Business environment and growth potential of micro and small manufacturing enterprises in Uganda. Afr. Dev. Rev. 2011, 23, 352-365. [CrossRef]

85. Manor, U.; Desiana, P.M. Work-life balance, motivation and personality of MSE owners on firm performance in Greater Jakarta. Pertanika J. Soc. Sci. Humanit. 2018, 26, 127-138.

86. Atnafu, D.; Balda, A. The impact of inventory management practice on firms' competitiveness and organizational performance: Empirical evidence from micro and small enterprises in Ethiopia. Cogent Bus. Manag. 2018, 5, 1503219. [CrossRef]

87. De Amorim Braga, F.J.; De Souza Silvestre, F.; De Oliveira, U.R. Analysis of individual micro-entrepreneur vision from the perspective of financial management. Braz. J. Oper. Prod. Manag. 2018, 15, 182-192. [CrossRef]

88. Shibia, A.; Barako, D.G. Determinants of micro and small enterprises growth in Kenya. J. Small Bus. Enterp. Dev. 2017, 24, 105-118. [CrossRef] 
89. Simeyo, O.; Martin, L.; Nyamao, N.R.; Patrick, O.; Odondo, A.J. Effect of provision of micro finance on the performance of micro enterprises: A study of youth micro enterprises under Kenya Rural Enterprise Program (K-REP), Kisii County, Kenya. Afr. J. Bus. Manag. 2011, 5, 8290-8300. [CrossRef]

90. Sulistya, G.A.; Darwanto, D. Transaction cost of micro and small enterprises financing. Econ. J. Emerg. Mark. 2016, 8, 171-186. [CrossRef]

91. Xu, B.; Climent, R.C.; Wang, Y.; Xiao, Y. Financial support for micro and small enterprises: Economic benefit or social responsibility? J. Bus. Res. 2020, 115, 266-271. [CrossRef]

92. Aga, G.A.; Reilly, B. Access to credit and informality among micro and small enterprises in Ethiopia. Int. Rev. Appl. Econ. 2011, 25, 313-329. [CrossRef]

93. Cassells, S.; Lewis, K.V. Environmental management training for micro and small enterprises: The missing link? J. Small Bus. Enterp. Dev. 2017, 24, 297-312. [CrossRef]

94. Leoneti, A.; Nirazawa, A.; Oliveira, S. Proposal of sustainability index as a self-assessment tool for micro and small enterprises (MSEs). Revista de Gestão REGE 2016, 23, 349-361. [CrossRef]

95. Agyapong, A.; Essuman, D.; Afia Kesewa Yeboah, L. Performance implications of strategic planning and marketing capability in micro and small businesses in an emerging African economy: A contingent resource-based view. J. Small Bus. Entrep. 2021, 33, 29-48. [CrossRef]

96. De Paulla, C.R.; Hamza, K.M. Quality Management and Innovation: Evidence from companies in the food sector in west region of Goiás. Rev. Gestão Desenvolv. 2015, 12, 165-178.

97. Ya'kob, S.A.; Jusoh, W.J.W. The effect of supply chain linkage on micro and small enterprises' performance. Int. J. Bus. Soc. 2016, 17, 99-112. [CrossRef]

98. Cardoso, H.H.R.; Gonçalves, A.D.; Carvalho, G.D.G.; Carvalho, H.G. Evaluating innovation development among Brazilian micro and small businesses in view of management level: Insights from the local innovation agents program. Eval. Program Plan. 2020, 80, 101797. [CrossRef] [PubMed]

99. Chege, S.M.; Wang, D.; Suntu, S.L. Influence of technology innovation intensity on firm performance: Technology innovation on firm performance-case of Kenya. Int. J. Technol. Hum. Interact. 2020, 16, 34-52. [CrossRef]

100. Laguir, I.; Besten, M.D.; Elbaz, J.; Stekelorum, R. Sowing the seeds: The impact of initial ties on growth and innovation among micro and small firms. Econ. Bull. 2017, 37, 1021-1032.

101. Laguir, I.; Besten, M.D. The influence of entrepreneur's personal characteristics on MSEs growth through innovation. Appl. Econ. 2016, 48, 4183-4200. [CrossRef]

102. Severo, E.A.; Sbardelotto, B.; Guimarães, J.C.F.; Vasconcelos, C.R.M. Project management and innovation practices: Backgrounds of the sustainable competitive advantage in Southern Brazil enterprises. Prod. Plan. Control 2020, 31, 1276-1290. [CrossRef]

103. Vasconcelos, R.; Oliveira, M. A inovação faz a diferença? Uma análise do desempenho das micro e pequenas empresas na indústria de serviços de alimentação. Innov. Manag. Rev. 2018, 15, 137-154. [CrossRef]

104. Walter, C.E.; Veloso, C.M.; Fernandes, P.O. The determinants of innovation in micro and small enterprises in the northeast of Brazil. Quality 2019, 20, 84-88.

105. Walter, C.E.; Veloso, C.M.; Fernandes, P.O. Measuring the degree of innovation in micro and small enterprises in the Northeast of Brazil. Holos 2019, 35, 1-13. [CrossRef]

106. Perekwa, G.B.; Prinsloo, T.; Deventer, J.P. Impact of mobile technology on micro and small enterprises in Zimbabwe in the post-hyperinflation economic era. Afr. J. Inf. Syst. 2016, 8, 3.

107. Berne, D.F.; Coda, R.; Krakauer, P.; Donaire, D. The innovation challenge in micro and small enterprises (MSE) An exploratory study at São Paulo metropolitan region. Innov. Manag. Rev. 2019, 16, 235-252. [CrossRef]

108. Gicã, O.A.; Balint, C.I. Planning practices of SMEs in north-western region of Romania-An empirical investigation. Procedia Econ. Financ. 2012, 3, 896-901. [CrossRef]

109. Malaquias, R.F.; Hwang, Y. Firms' size and use of information and communication technologies: Empirical evidence on small businesses in Brazil. Inf. Dev. 2016, 32, 1613-1620. [CrossRef]

110. Moyi, E.D. Networks, information and small enterprises: New technologies and the ambiguity of empowerment. Inf. Technol. Dev. 2003, 10, 221-232. [CrossRef]

111. Quelhas, F.C. Impact of information technology investments in organizational strategic variables and in performance of micro and small enterprises (MSBE). J. Manag. Technol. 2019, 19, 138-164. [CrossRef]

112. Skýpalová, R.; Kučerová, R.; Blašková, V. Development of the Corporate Social Responsibility Concept in Small and Medium-Sized Enterprises. Prague Econ. Pap. 2016, 25, 287-303. [CrossRef]

113. Vorkapić, M.; Radovanović, F.; Ćoćkalo, D.; Đorđević, D. Npd in small manufacturing enterprises in Serbia. The. Vjesn.-Tech. Gaz. 2017, 24, 327-332. [CrossRef]

114. Woida, L.M. Seeking, accessing, sharing and using information in Brazilian micro and small enterprises. Rev. Sist. Inf. Doc. 2019, 13, 51-56.

115. Gavurova, B.; Cepel, M.; Belas, J.; Dvorský, J. Strategic management in SMEs and its significance for enhancing the competitiveness in the V4 countries-A comparative analysis. Manag. Mark. 2021, 15, 557-569. [CrossRef] 
116. Nordhagen, S.; Igbeka, U.; Rowlands, H.; Tench, J.; Shine, R.S.; Heneghan, E. COVID-19 and small enterprises in the food supply chain: Early impacts and implications for longer-term food system resilience in low- and middle-income countries. World Dev. 2021, 141, 105405. [CrossRef]

117. Păunescu, C.; Mátyus, E. Resilience measures to dealing with the COVID-19 pandemic. Evidence from Romanian micro and small enterprises. Manag. Mark. 2020, 15, 439-457. [CrossRef]

118. Marques, N.A.Z.; Quintero, J.M.M.; Sáenz, F.I.M.; Almazán, D.A. Critical Success Factors in Implementing IT in MSMEs. Cuad. Adm. 2019, 35, 3-14. [CrossRef]

119. Porter, M.E.; Kramer, M.R. Creating Shared Value. Harv. Bus. Rev. 2011, 89, 62-77.

120. Alonso, A.D.; Bressan, A. A resource-based view of the firm and micro and small Italian wine firms. Int. J. Wine Bus. Res. 2016, 28, 349-368. [CrossRef]

121. Fatoki, O.; David Garwe, D. Obstacles to the growth of new SMEs in South Africa: A principal component analysis approach. Afr. J. Bus. Manag. 2010, 4, 729-738. [CrossRef]

122. World Health Organization-WHO. A Year without Precedent: WHO's COVID-19 Response. 2020. Available online: https: / www.who.int/news-room/spotlight/a-year-without-precedent-who-s-covid-19-response (accessed on 10 October 2020).

123. International Labour Organization-ILO. COVID-19 and Enterprises. 2020. Available online: https://www.ilo.org/empent/ areas/covid-19/lang--en/index.htm (accessed on 10 August 2020).

124. Mcgrath, S. 'Skills for productive citizenship for all': The place of skills development for micro and small enterprises in South Africa. J. Educ. Work 2005, 18, 111-125. [CrossRef] 